UNI VERSI DADE DE SÃO PAULO

FACULDADE DE ODONTOLOGI A DE RI BEI RÃO PRETO

DEPARTAMENTO DE ODONTOLOGI A RESTAURADORA

PROGRAMA DE PÓS-GRADUAÇÃO EM ODONTOLOGI A RESTAURADORA - ENDODONTI A

Organoclorados gerados pela ação de hipoclorito de sódio em substrato orgânico (dentina e polpa).

TIAGO GI LIOLI VARISE

Ribeirão Preto 



\section{Organoclorados gerados pela ação de hipoclorito de sódio em substrato orgânico (dentina e polpa).}

Dissertação de Mestrado apresentada à Faculdade de Odontologia de Ribeirão Preto da Universidade de São Paulo para a obtenção do grau de Mestre em Ciências - Programa: Odontologia Restauradora - Área de concentração: Odontologia Restauradora (Opção: Endodontia).

Orientador: Prof. Dr. J esus Djalma Pécora

\section{Ribeirão Preto}


Autorizo a reprodução e divulgação total ou parcial deste trabalho, por qualquer meio convencional ou eletrônico, para fins de estudo e pesquisa, desde que citada à fonte.

\section{FI CHA CATALOGRÁFICA}

Varise, Tiago Gilioli

Organoclorados gerados pela ação de hipoclorito de sódio em substrato orgânico (dentina e polpa). Ribeirão Preto, 2013.

120 p.: il.; $27 \mathrm{~cm}$.

Dissertação de Mestrado apresentada à Faculdade de Odontologia de Ribeirão Preto da Universidade de São Paulo (FORP-USP). Área de concentração: Odontologia Restauradora, subárea Endodontia.

Orientador: Prof. Dr. J esus Djalma Pécora

1. Hipoclorito de Sódio 2. Cromatografia Gasosa 3. Espectrometria de massas.

4. Organoclorado 

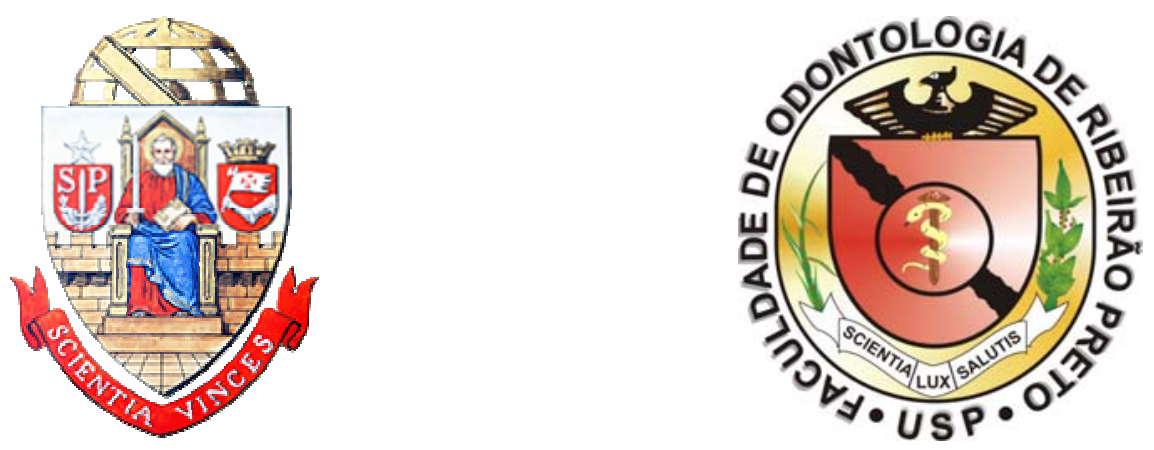

Este trabalho de pesquisa foi realizado no Laboratório de Pesquisas em Endodontia, no Laboratório de Gerenciamento de Resíduos Odontológicos (LAGRO) do Departamento de Odontologia Restauradora da Faculdade de Odontologia de Ribeirão Preto e no Laboratório de Espectrometria de Massas e Produtos Naturais do Departamento de Química da Faculdade de Filosofia, Ciências e Letras de Ribeirão Preto (FFCLRP) da Universidade de São Paulo. 



\section{FOLHA DE APROVAÇÃO}

Membros da Comissão Julgadora da Dissertação de Mestrado de Tiago Gilioli Varise, apresentada ao Departamento de Odontologia Restauradora - Endodontia da Faculdade de Odontologia de Ribeirão Preto, Universidade de São Paulo, ___ / ___ l

\section{Comissão J ulgadora:}

1) Prof.(a).Dr.(a).:

Instituição:

Julgamento:

Assinatura:

2) Prof.(a).Dr.(a).:

Instituição:

Julgamento:

Assinatura:

3) Prof.(a).Dr.(a).:

Instituição:

Julgamento:

Assinatura: 

"Conheça todas as teorias, domine todas as técnicas, mas ao tocar uma alma humana seja apenas outra alma humana." Carl Gustav Jung 

Dedicatória 

Dedico especialmente este trabalho...

Aos meus pais, Luiz Evanir Varise e Maria Madalena Gilioli Varise, que foram os meus maiores torcedores frente às competições que o Universo tem colocado em minha vida fazendo, de mim e dos meus irmãos, homens dedicados no caminho do sucesso pessoal.

Aos meus irmãos César Gilioli Varise, Vitor Gilioli Varise e minha cunhada Indri Nogueira Varise, pelos momentos de convivência, aprendizagem e compreensão fazendo do convívio entre família uma escola com choros e sorrisos que tornou cada um, da sua maneira, um filho único para nossos pais.

À minha noiva Lígia Monsef Gavaldão, por toda paciência nos dias que o humor não estava desenhado no meu rosto, por todos os momentos que esteve ao meu lado apoiando para que eu pudesse finalizar este trabalho e por dividir comigo os melhores planos para o futuro!

À família Gavaldão pelo acolhimento e apreço! Sempre dedicaram atenção, carinho, respeito e amizade à mim! Muito obrigado! 



\section{Agradecimentos}



A Deus, pela sabedoria dada para que cada escolha fosse tomada buscando 0 caminho certo e pelas portas que sempre fez-se abrir em minha vida para chegar as oportunidades da realização de todos os meus sonhos.

Ao meu orientador, Prof. Dr. Jesus Djalma Pécora, por ter sido um grande mestre na Endodontia e por dedicar tempo ao me dar orientações que ultrapassaram os ensinamentos para a conclusão deste trabalho, ensinando lições que valerão pela vida.

Ao Prof. Dr. Manoel Damião Sousa Neto, por todas as oportunidades dadas desde a graduação e pela confiança dedicada, principalmente nos trabalhos clínicos da minha vida acadêmica.

Ao Prof. Dr. Antônio Miranda da Cruz Filho, pela educação que sempre fez-se presente em nossas conversas.

Aos demais professores (as) do programa de pós-graduação em Endodontia Prof. Dr. Ricardo Gariba da Silva, Ricardo Novak Savioli, Luis Pascoal Vansan e Isabel Cristina Fröner, pelos ensinamentos transmitidos.

A Dra. Débora Fernandes Costa Guedes, pelo tempo dedicado e o conhecimento emprestado para a realização de cada passo desse projeto. Foi sua busca pela solução dos problemas que apareciam no decorrer do trabalho que tornou possível a realização dos experimentos.

Ao Departamento de Química da Faculdade de Filosofia, Ciências e Letras de Ribeirão Preto (FFCLRP) da Universidade de São Paulo, professores e funcionários por toda contribuição e recursos nas análises dos resultados. 
Aos colegas de turma Geraldo Celso da Silva Onety, Polliana Vilaça, Daniel Leonel, em especial à Graziela Bianchi Leoni e Luis Eduardo Souza Flamini pelo convívio e conversas durante a pós-graduação.

Ao Prof. Dr. José Antônio Brufato Ferraz que faz parte da minha formação como endodontista ensinando, além da arte profissional, lições que a vida exige a prova de nós antes mesmo do entendimento das suas aulas.

Ao funcionário Carlos Feitosa dos Santos, Secretário do Programa de PósGraduação em Odontologia Restauradora, pela atenção dedicada a mim e a cada aluno da pós-graduação, mostrando-se sempre solícito e responsável quando cada um de nós precisou de sua ajuda. Admiro sua humildade e educação.

Ao colega Reginaldo Santana da Silva, técnico do Laboratório de Pesquisa em Endodontia da Faculdade de Odontologia de Ribeirão Preto pelo companheirismo e bom humor dispensado às pessoas que estavam à sua volta.

Às funcionárias Luiza Godoi Pitol, Rosângela Angelini, Maria Amália Viesti de Oliveira e Maria Isabel Francisco Miguel, por toda ajuda oferecida sempre que precisei.

Às funcionárias Isabel Cristina Galino Sola e Regiane Moi Sacilotto, secretárias do Setor de Pós-Graduação da Faculdade de Odontologia de Ribeirão Preto, pela atenção e orientações concedidas durante a pós-graduação.

À CAPES (Coordenação de Aperfeiçoamento de Pessoal de Nível Superior), pela ajuda financeira disponibilizada durante o curso. 
À Faculdade de Odontologia de Ribeirão Preto da Universidade de São Paulo, pela formação como graduando, especialista e pela chance de realizar este trabalho.

À Universidade de São Paulo, em especial ao Campus de Ribeirão Preto, pela seriedade dedicada na educação de seus alunos e pelas condições oferecidas para o meu crescimento profissional e pessoal. 

Sumairio 



\section{Resumo}

Abstract

\section{Lista de Abreviaturas}

\section{Lista de Figuras}

\section{Lista de Tabelas}

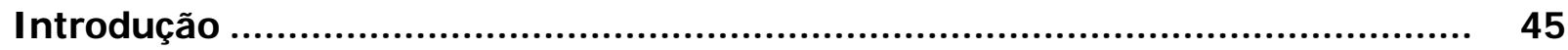

Proposição.......................................................................................................... 61

Materiais e Métodos............................................................................................ 65

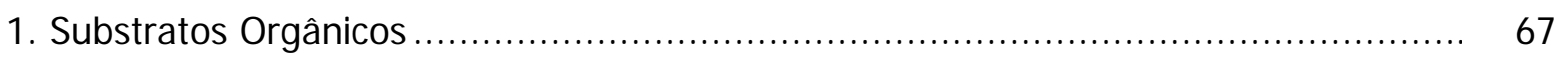

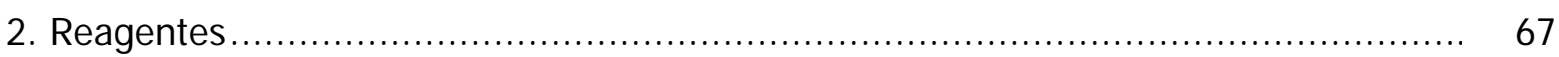

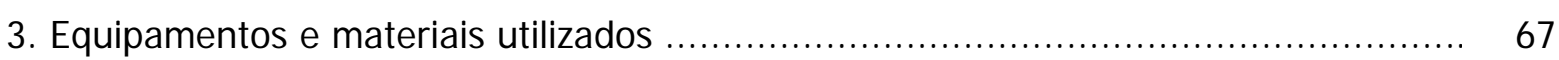

4. Preparo dos substratos e dos reagentes............................................ 69

5. Método de extração para análise em Cromatografia Gasosa acoplada em Espectrometria de Massas (CG-MS) ................................................... 70

6. Otimização do CG-MS para análise dos produtos gerados pela decomposição do

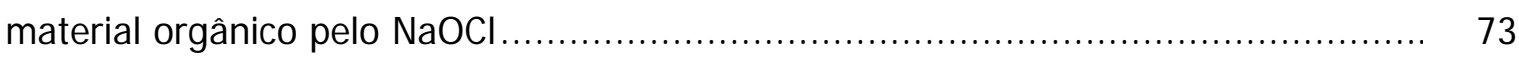

7. Curva de calibração das amostras ................................................. 74

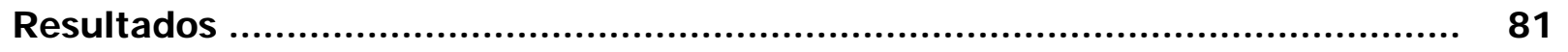

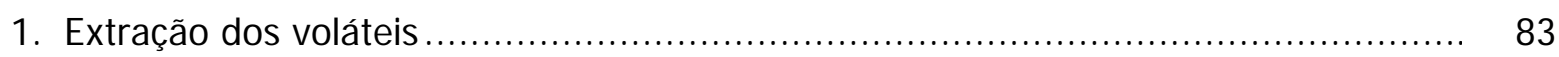

2. Extração da fase aquosa ............................................................. 91

3. Análise das áreas dos picos obtidos na cromatografia gasosa dos compostos voláteis (relação concentração do hipoclorito de sódio e

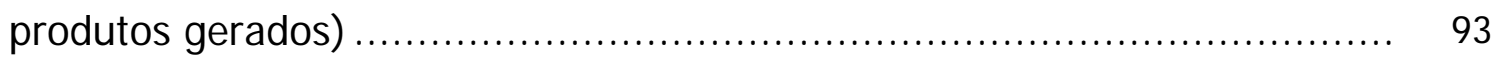

Discussão ........................................................................................ 97

Conclusões ................................................................................................. 103

Referências Bibliográficas .................................................................. 107 

Albreviaturas 



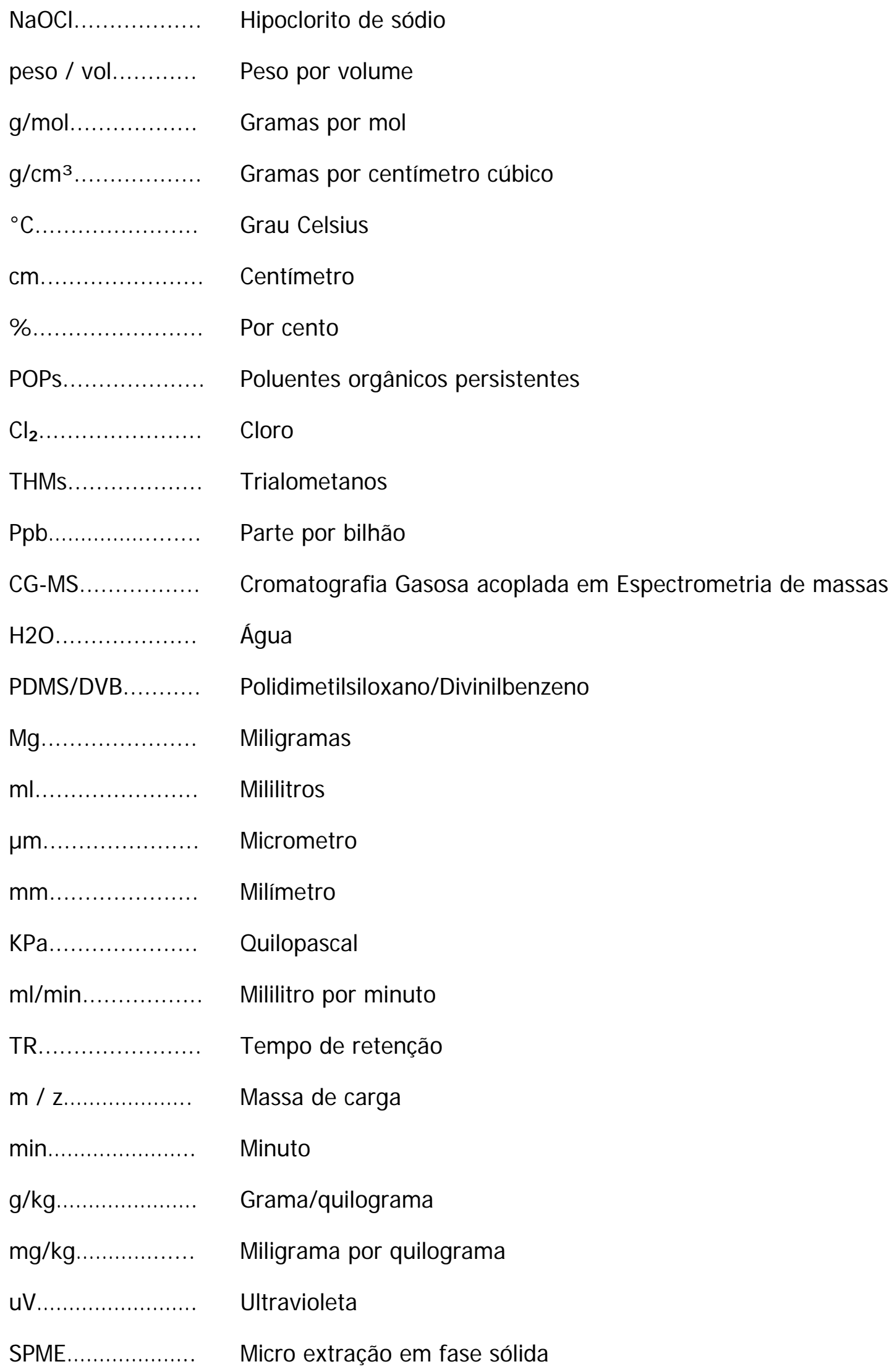



Lista de Figuras 



\section{LISTA DE FIGURAS}

Figura 1. Vista geral do equipamento (Cromatógrafo Gasoso acoplado com Espectrômetro de Massas) utilizado nas análises

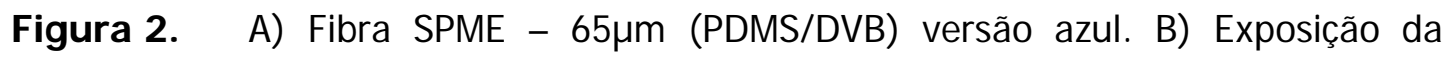
fibra. C) Holder para fibra SPME.

Figura 3. Processo de preparo do substrato orgânico. A) Secção da coroa e raíz do dente bovino. B) Remoção da polpa. C) Preparo da superfície externa da raíz para remoção da camada cementária. D) Fragmentação da raíz para facilitar sua trituração. E) Moinho de bola MLW ${ }^{\circledR}$ utilizado para triturar os fragmentos de dentina bovina

Figura 4. Inserção da fibra SPME dentro do recipiente através da membrana para adsorção dos produtos voláteis gerados pela dissolução do material orgânico em contato com diferentes concentrações de $\mathrm{NaOCl}$.. 71

Figura 5. Injeção da fibra impregnada no CG-MS para análise dos compostos

Figura 6. Análise imediata da fibra em CG-MS antes do contato com qualquer reagente ou produto

Figura 7. Análise imediata dos produtos volatilizados após exposição da fibra apenas ao $\mathrm{NaOCl}$

Figura 8. Análise imediata dos produtos volatilizados após exposição da fibra apenas à polpa bovina.

Figura 9. Análise imediata dos produtos volatilizados após exposição da fibra apenas à dentina bovina......

Figura 10. Análise em CG-MS do solvente éter etílico puro utilizado para as extrações em fase líquida

Figura 11. Análise cromatográfica inicial dos produtos formados na reação entre $\mathrm{NaOCl}$ e dentina bovina.

Figura 12. Zoom de 1 - 4 min da análise imediata dos produtos voláteis formados na reação entre $\mathrm{NaOCl} /$ dentina bovina

Figura 13. Espectro de massas referente ao pico com $T R=2,15 \mathrm{~min}$. da Figura 12, correspondendo ao clorofórmio, obtido após dessorção da fibra........

Figura 14. Ilustração da estrutura molecular do organoclorado clorofórmio 
Figura 15. Zoom de 4 - $6 \mathrm{~min}$ da análise imediata dos produtos voláteis formados na reação entre $\mathrm{NaOCl}$ e a dentina bovina.

Figura 16. Espectro de massas referente ao pico com $T R=5,32 \mathrm{~min}$. da figura 15, correspondendo ao benzaldeído, obtido após dessorção da fibra...... 86

Figura 17. Ilustração da estrutura molecular do benzaldeído 86

Figura 18. Zoom de 6 - 8 min da análise imediata, dos produtos voláteis formados na reação entre $\mathrm{NaOCl}$ e a dentina

Figura 19. Espectro de massas referente ao pico com $T R=6,3 \mathrm{~min}$. da Figura 18, correspondendo ao hexacloroetano, obtido após dessorção da fibra.

Figura 20. Ilustração da estrutura molecular do hexacloroetano

Figura 21. Espectro de massas referente ao pico com $T R=6,7 \mathrm{~min}$. da Figura 18 correspondendo ao diclorometilbenzeno, obtido após dessorção da fibra.

Figura 22. Ilustração da estrutura molecular do diclorometilbenzeno 88

Figura 23. Análise imediata dos produtos voláteis formados na reação entre $\mathrm{NaOCl}$ e polpa bovina

Figura 24. Zoom de 1 - 4 min da análise imediata dos produtos voláteis formados na reação entre $\mathrm{NaOCl} /$ polpa bovina

Figura 25. Zoom de 4 - 6 min da análise imediata dos produtos voláteis formados na reação entre $\mathrm{NaOCl} /$ polpa bovina

Figura 26. Zoom de 6 - 8 min da análise imediata dos produtos voláteis formados na reação entre $\mathrm{NaOCl} /$ polpa bovina

Figura 27. Extração com éter etílico da fase aquosa dos produtos formados na reação entre $\mathrm{NaOCl} 5,25 \%$ / dentina bovina e $\mathrm{NaOCl} 5,25 \%$ + / polpa bovina

Figura 28. Reações químicas entre os componentes do tecido pulpar e as substâncias presentes na solução de hipoclorito de sódio 
Lista de Tabelas 



\section{LISTA DE TABELAS}

Tabela I. Áreas dos picos obtidos na cromatografia gasosa dos compostos voláteis liberados na reação entre a dentina e o hipoclorito de sódio $(\mathrm{NaOCl})$ nas diferentes concentrações testadas...............................

Tabela II- Áreas dos picos obtidos na cromatografia gasosa dos compostos voláteis liberados na reação entre a polpa e o hipoclorito de sódio ( $\mathrm{NaOCl})$ nas diferentes concentrações testadas. 

Resumo 

VARISE, T. G. Organoclorados gerados pela ação de hipoclorito de sódio em substrato orgânico (dentina e polpa). 2013. 120p. Dissertação (Mestrado) - Faculdade de Odontologia de Ribeirão Preto, Universidade de São Paulo, Ribeirão Preto, 2013.

O presente trabalho teve como objetivo identificar, por meio da Cromatografia Gasosa acoplada à Espectrometria de Massas (CG-MS), os produtos formados pelo contato do hipoclorito de sódio $(\mathrm{NaOCl})$ com polpa e dentina bovina. Foram selecionados dentes incisivos superiores bovinos recém-extraídos. Os dentes bovinos tiveram suas coroas separadas das raízes, em seguida o tecido pulpar foi removido com o auxílio de limas Hedströem e armazenado, a porção radicular seccionada teve sua superfície externa preparada com pontas diamantadas para remoção da camada cementária, seccionada em pequenos fragmentos e em seguida foi triturada em um moinho de bola a fim de obter micropartículas de dentina. Foram preparadas três diferentes concentrações de $\mathrm{NaOCl}$ $(0,5 \%, 2,5 \%$ e 5,25\%). Para análise dos produtos formados na fase volátil, $11 \mathrm{mg}$ de polpa foi colocada em contato com as diferentes concentrações da solução halógena e mantida em contato sob agitação até que fosse observada a total dissolução da amostra, em seguida a fibra de microextração em fase sólida (SPME) era exposta dentro do recipiente através da membrana da tampa por 15 minutos para efetuar a adsorção dos produtos formados e imediatamente injetada no CG-MS para análise. Para dentina, 30mg da amostra foi mantida em contato com as três concentrações do $\mathrm{NaOCl}$ sob agitação por 15 minutos, em seguida a fibra de SPME era exposta dentro do recipiente para adsorção dos produtos formados e imediatamente injetada no CG-MS para análise. Foi utilizado o mesmo protocolo para análise da fase aquosa, deste modo, após a remoção das fibras para a análise dos compostos voláteis, foi feita a extração da solução final obtida por meio de éter etílico puro, padronizando-se a mistura de $2 \mathrm{ml}$ da solução $+2 \mathrm{ml}$ de éter e mantendo sob agitação durante 5 minutos. Seguida a agitação, a fase suspensa da mistura era aspirada separando 0 éter da fase aquosa da solução obtida. 0 éter contendo os produtos resultantes da interação química dos compostos orgânicos da dentina ou polpa com o $\mathrm{NaOCl}$ nas suas diferentes concentrações era filtrado e em seguida injetado no CG-MS para análise da fase aquosa das amostras. As análises da fase volátil e aquosa tanto da dentina quanto da polpa mostraram que houve formação de clorofórmio, hexacloroetano, diclorometilbenzeno e benzaldeído, tendo os três primeiros compostos estrutura química que os caracterizam como organoclorados. Conclui-se que houve formação de compostos organoclorados quando o $\mathrm{NaOCl}$ foi colocado em contato com substrato orgânico (polpa ou dentina bovina) em todas as concentrações estudadas e que esta formação foi diretamente proporcional à concentração do $\mathrm{NaOCl}$ utilizado.

Palavras-chave: Hipoclorito de Sódio; Cromatografia Gasosa; Espectrometria de massas; Organoclorado. 

Astbstract 

VARISE, T. G. Organochlorine generated by the action of sodium hypochlorite on organic substrate (dentin and pulp). 2013, 120 p. Dissertação (Mestrado) - Ribeirão Preto Dental School, University of São Paulo, Ribeirão Preto, 2013.

The aim of this study was to identify, by means of gas chromatography-mass spectrometry (GC-MS), the products formed from the contact of sodium hypochlorite $(\mathrm{NaOCl})$ with bovine pulp and dentin. Freshly extracted maxillary bovine incisors were selected for this purpose. The crowns were separated from the roots and the pulp tissue was removed with Hedströem files and stored. The root portion had its external surface prepared with diamond burs to remove the cementum layer and was sectioned into small fragments, which were ground in a ball windmill to obtain dentin microparticles. Three $\mathrm{NaOCl}$ concentrations were prepared $(0.5 \%, 2.5 \%$ and $5.25 \%)$. For analysis of the products formed in the volatile phase, $11 \mathrm{mg}$ of pulp tissue was placed in contact with the different halogen solution concentrations and kept in contact under constant agitation until complete tissue dissolution occurred. Next, the solid phase microextraction (SPME) fiber was exposed inside the container through the cover membrane for 15 minutes for adsorption of the formed products and immediately injected into the GC-MS equipment for analysis. For the dentin, $30 \mathrm{mg}$ of sample was kept in contact with the three $\mathrm{NaOCl}$ concentrations under constant agitation for 15 minutes, and then the SPME fiber was exposed inside the container through the cover membrane for 15 minutes for adsorption of the products and immediately injected into the GC-MS equipment for analysis. The same protocol was used for analysis of the aqueous phase. In this way, after removal of the fibers for analysis of the volatile compounds, the final solution was extracted using pure ethyl ether, standardizing the mixture of $2 \mathrm{~mL}$ of solution plus $2 \mathrm{~mL}$ of ether, under constant agitation during 5 minutes. Next, the suspended phase of the mixture was aspirated, separating the ether from the aqueous phase of the obtained solution. The ether containing the products resulting from the chemical interaction between dentin/pulp organic compounds with the different $\mathrm{NaCl}$ concentrations was filtered and then injected into the GC-MS equipment for analysis of the aqueous phase of the samples. Analysis of the aqueous and volatile phases of both dentin and pulp showed formation of chloroform, hexachloroethane, dichloro-methyl-benzene and benzaldehyde, the first three compounds exhibiting chemical structure that characterize them as organochlorides. It may be concluded that there is formation of organochlorine compounds when $\mathrm{NaOCl}$ was placed in contact with an organic substrate (bovine pulp or dentin) at all tested concentrations and that it was directly proportional to the $\mathrm{NaOCl}$ concentration.

Key words: Sodium Hypochlorite; gas chromatography; Mass spectrometry; organochlorine. 

Introdução 

O sucesso do tratamento endodôntico (cura e reparo dos tecidos envolvidos) vem sendo pesquisado desde o final do século XIX por profissionais e pesquisadores que se dedicavam à terapêutica endodôntica (KIRK, 1893; CALLAHAN, 1894) baseada na limpeza, antissepsia e a conformação do canal radicular para posterior obturação (VERSIANI et al, 2011).

O êxito do tratamento endodôntico é atingido quando se respeita as diferentes fases: preparo biomecânico, controle da desinfecção e obturação dos canais radiculares proporcionando ao tecido periapical níveis compatíveis para seu reparo (METZGER et al, 2010; SIQUEIRA, 2011).

O preparo biomecânico, compreendido como a fase de ação dos instrumentos e soluções químicas no interior do canal radicular, é uma das etapas que exige muito cuidado no tratamento endodôntico e tem sido insistentemente estudado há mais de um século por vários pesquisadores demonstrando a importância do assunto (CALLAHAM, 1894; GROSSMAN, 1943; STEWART, 1955; INGLE \& ZELDOW, 1958; GROSSMAN, 1960; SCHILDER, 1974; WEINE, 1976; LEONARDO \& LEAL, 1991; DEUS, 1992; ESTRELA et al, 2003; PAQUÉ \& PETERS, 2011; HASHEM et al, 2012; RIBEIRO et al, 2012).

A limpeza dos canais radiculares é dificultada principalmente pelas variações da anatomia interna dos dentes que impede a atuação dos instrumentos em determinadas áreas (VERSIANI et al, 2011; SOUZA et al, 2012), assim julga-se extremamente importante a utilização de substâncias químicas auxiliando na dissolução dos tecidos (PALAZZl et al, 2012) e na diminuição do número de microrganismos (ESTRELA et al, 2007; GOMES et al, 2009; RÔÇAS \& SIQUEIRA, 2011a; WANG et al, 2012; PAIVA et al, 2013). Portanto, essas soluções auxiliares devem apresentar propriedades físico-químicas que as qualifiquem para esses atos, tais como: 1- ação física pela movimentação hidráulica (irrigação e aspiração) que remove do interior dos canais radiculares detritos que estejam dissolvidos ou em suspensão; e 2- ação química propriamente dita, pois devem possuir propriedades antimicrobiana e solvente de tecidos vivos e necróticos.

$\mathrm{Na}$ busca pela solução irrigante ideal, ao longo dos anos várias soluções químicas auxiliares da instrumentação têm sido desenvolvidas, defendidas e empregadas. 
O hipoclorito de sódio possui fórmula molecular $\mathrm{NaOCl}$, massa molar de $74,44 \mathrm{~g} / \mathrm{mol}$, densidade de 1.07 a $1.14 \mathrm{~g} / \mathrm{cm}^{3}$, ponto de ebulição em torno de $101^{\circ} \mathrm{C}$, é totalmente miscível em água e possui tensão superficial em torno de 70 dinas por cm (MILANO et al. 1963, PÉCORA et al. 1992 e SPANÓ et al, 2001)

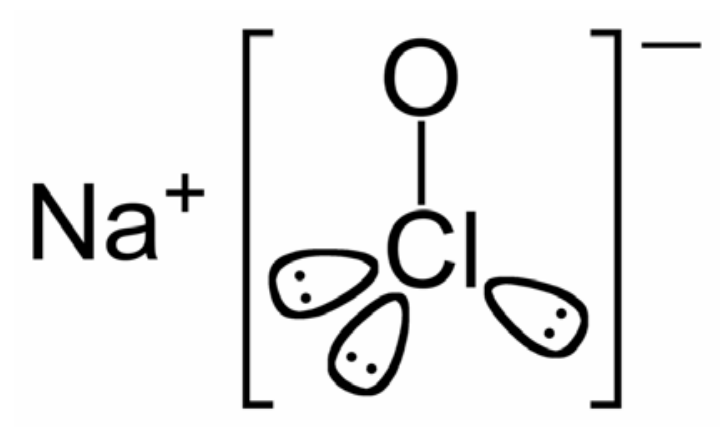

O hipoclorito de sódio não existe no estado de pó, mas somente em solução aquosa. Estando em solução aquosa, encontra-se em um equilíbrio químico dinâmico, onde pode apresentar-se como um sal não dissociado, dando origem a outras substâncias ou apresentando-se também totalmente dissociada. Essa solução aquosa de hipoclorito de sódio, devido ao seu equilíbrio químico dinâmico, pode ser representada pela seguinte reação química (Reação I):

$$
\mathrm{NaOCl}+\mathrm{H}_{2} \mathrm{O} \Leftrightarrow \mathrm{NaOH}+\mathrm{HOCl} \Leftrightarrow \mathrm{Na}^{+}+\mathrm{OH}^{-}+\mathrm{H}^{+}+\mathrm{OCl}^{-}->\mathrm{O}_{2}+\mathrm{Cl}_{2}
$$

As reações químicas entre os componentes do tecido pulpar e as substâncias presentes na solução de hipoclorito de sódio responsáveis pelo processo de dissolução tecidual, como citadas por PUCCI (1945) e SPANÓ et al (2001), podem ser vistas a seguir: 


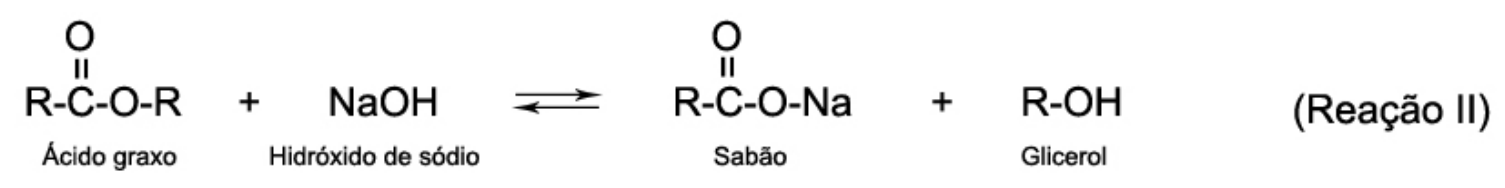<smiles>[R]C(N)OC(=O)O</smiles><smiles>[R]C(N)OC(=O)O</smiles>

Pela análise ou interpretação das reações I a IV pode-se entender as ações do hipoclorito de sódio:

- O hidróxido de sódio é um potente solvente orgânico e de gordura formando sabões (saponificação) (SIRTES et al, 2005; CLARKSON et al, 2006).

- Eficaz em condições aeróbicas e anaeróbicas na eliminação de microrganismos (YANG et al, 1995).

- $\mathrm{O}$ ácido hipocloroso é um potente agente antimicrobiano por liberar cloro nascente que se combina com o grupo amina das proteínas, formando as cloraminas. O ácido hipocloroso ( $\mathrm{HOCl})$ sofre decomposição pela ação da luz, do ar e do calor liberando cloro livre e, em secundariamente oxigênio nascente.

$$
4 \mathrm{HOCl} \rightarrow \mathrm{O}_{2}+2 \mathrm{H}_{2} \mathrm{O}+2 \mathrm{Cl}_{2}
$$

- $\quad$ Neutraliza produtos tóxicos - atua sobre as proteínas.

- Ação antimicrobiana (ESTRELA et al, 2003; PAIVA et al, 2013). 
- $\mathrm{pH}$ alcalino - Neutraliza a acidez do meio, tornando-o impróprio para o desenvolvimento bacteriano.

- Desidrata e solubiliza proteínas, transformando-as em materiais facilmente elimináveis.

- Em baixas concentrações e neutralizadas, como a Solução de Dakin, não irrita os tecidos vivos (HOLLAND et al, 1992).

- Agente clareador - potente fonte de agente oxidante.

- Agente desodorizante por atuar sobre produto em decomposição, transformando amina em cloramina.

Os hipocloritos são conhecidos como compostos halogenados e segundo PUCCI (1945), a introdução de uma solução de hipoclorito de sódio no arsenal terapêutico data de 1792 com o nome de água de Javelle, uma mistura de hipoclorito de sódio e potássio. Em 1820, o químico francês La Barraque introduziu o hipoclorito de sódio a 2,5\%, que ficou conhecido como licor de La Barraque e era utilizada como desinfetante de feridas.

DAKIN, H. D. em 1915 observou que ao tratar feridas de guerra com hipoclorito de sódio a 2,5\% (Solução de La Barraque), obtinha-se desinfecção, porém a cicatrização da ferida era demorada. Foi constatado que o mesmo era resultado mesmo quando feridas eram tratadas com hipoclorito de sódio a 0,5\%. Ele observou que a demora de cicatrização ocorria devido o grande teor de hidróxido de sódio presente nas soluções de hipoclorito, independente de sua concentração. Com base neste raciocínio, Dakin neutralizou a solução de hipoclorito de sódio a 0,5\% pH 11, com ácido bórico $(0,4 \%)$. A partir de então, com um pH próximo do neutro, as soluções de hipoclorito de sódio conseguiu manter seu poder de desinfecção das feridas sem o efeito indesejável da ação das hidroxilas sobre os tecidos vivos. Ele verificou que o hipoclorito de sódio, quer a $2,5 \%$ ou a $0,5 \%$ apresentava o mesmo $\mathrm{pH}$, em virtude das hidroxilas livres. Com a adição do ácido bórico ocorria a formação do borato de sódio na solução, evitando assim a presença de hidroxilas livres, irritantes dos tecidos. 
Assim como a solução de Dakin é neutralizada com ácido bórico, soluções de hipoclorito de sódio a $0,5 \%$ neutralizada com bicarbonato de sódio recebem o nome de Solução de Dausfrene.

O líquido de Dakin teve seu uso difundido na Odontologia no ano de 1917 quando BARRETT relatou sua eficiência como agente antisséptico e no ano seguinte, em 1918, TAYLOR \& AUSTIN demonstraram a ação solvente do líquido de Dakin em tecidos necrosados e observaram, também, que essa solução era pouco irritante aos tecidos vivos.

Buscando soluções com maior poder de atuação de dissolução dos tecidos orgânicos e de combate aos microrganismos, a partir de observações clínicas feitas em 1936, WALKER iniciou o uso de hipoclorito de sódio com 5\% de cloro ativo em tratamentos endodônticos. Essa solução denominada Soda Clorada ou Soda Clorada Duplamente Concentrada passou a ser amplamente difundida como solução irrigante de canais radiculares.

GROSSMAN \& MEIMAN (1941) afirmaram a superioridade do poder de solvência de tecidos do hipoclorito de sódio a $5 \%$ em relação às outras substâncias utilizadas na época e em 1943, GROSSMAN iniciaria, baseado em suas pesquisas, o uso alternado da solução de hipoclorito de sódio 5\% com o peróxido de hidrogênio a 3\% (10 volumes) para aumentar o poder de limpeza da solução auxiliar ao conseguir a liberação de oxigênio nascente.

ESTRELA et al (2003) pesquisaram a atuação do hipoclorito de sódio e clorexidina a $2 \%$ como agentes antimicrobianos apontando a necessidade do contato direto do $\mathrm{NaOCl}$ com o microrganismo para o sucesso do controle da contaminação. Em 2007, ESTRELA et al pesquisaram a atuação de algumas soluções irrigantes, inclusive do $\mathrm{NaOCl}$, pelo tempo de 20 minutos e nenhuma solução foi capaz de eliminar E. faecalis no tempo estudado, apontando a importância do tempo de contato da solução com o microrganismo.

GOMES et al (2009) compararam a eficácia do hipoclorito de sódio a 2,5\% e do gel de clorexidina a $2 \%$ na eliminação lipopolissacarídeo bacteriano em dentes com necrose pulpar ou periodontite apical, confirmando a importância das soluções testadas na diminuição dos microrganismos existentes, porém alertando sobre a ineficácia de ambos na eliminação das endotoxinas dos canais radiculares infectados. 
Em 2010, RETAMOZO et al pesquisaram o poder de eliminação de Enterococcus faecalis por diferentes concentrações de $\mathrm{NaOCl}$ e em diferentes tempos concluindo que a eliminação da bactéria tem uma relação diretamente proporcional com a concentração do hipoclorito utilizada e o tempo de contato.

RÔÇAS \& SIQUEIRA (2011a) compararam a capacidade de eliminação de microrganismos utilizando hipoclorito de sódio a 2,5\% e clorexidina a 0,12\% durante o tratamento endodôntico concluindo que ambos conseguiram uma redução significativa no número de microrganismos, em canais radiculares infectados, sem diferenças significativas entre estas substâncias.

Ainda em 2011b, RÔÇAS \& SIQUEIRA estudaram o efeito do hipoclorito de sódio durante o preparo biomecânico e da pasta de hidróxido de cálcio como curativo entre sessões concluindo que os níveis de microrganismos foram substancialmente reduzidos após o preparo químico-mecânico e medicação intracanal, no entanto, a presença de níveis detectáveis de bactérias que persistem em muitos casos indica a necessidade da busca de estratégias mais eficazes no combate aos microrganismos.

O uso de sistemas ultrassônicos para auxiliar na diminuição dos microrganismos presentes no canal radicular foi estudado por vários pesquisadores como GRÜNDLING et al (2011) demonstrando que a agitação ultrassônica pode ajudar na limpeza do canal radicular, no entanto, o principal papel na eliminação de microrganismos é desempenhado pela solução irrigante.

SEET et al (2012) mostraram que o $\mathrm{NaOCl}$ diminui porém não elimina todos os microrganismos existentes no conduto, sendo necessário métodos complementares para auxiliar a diminuição da contaminação como o uso de sistemas ultrassônicos.

PAIVA et al (2012) apontaram a eficiência do preparo biomecânico utilizando $\mathrm{NaOCl}$ a 2,5\% como solução irrigante, porém aponta a importância de medicamentos intracanais entre sessões para auxíliar na diminuição dos microrganismos presente no conduto radicular.

A eficácia antimicrobiana do hipoclorito de sódio, com base no seu elevado pH (ação dos íons $\mathrm{OH}^{-}$), é semelhante ao mecanismo de ação do hidróxido de cálcio. 0 pH elevado do hipoclorito de sódio atua na integridade da membrana citoplasmática com uma inibição enzimática irreversível, causando alterações no metabolismo celular de biossíntese e degradação de fosfolipídios. Estudos recentes têm 
demonstrado que as alterações no $\mathrm{pH}$ podem alterar as capacidades antimicrobiana e proteolíticas destas soluções (ZEHNDER et al, 2002; CHRISTENSEN et al, 2008; CAMPS, 2009; AUBUT et al, 2010).

A partir de observações in vitro, SIRTES et al (2005) afirmaram que uma solução de $\mathrm{NaOCl}$ a $1 \%$ deve ser suficiente para dissolver todo o tecido da polpa no decorrer de uma sessão de tratamento endodôntico dependendo do tempo de atuação. Deve compreender-se que, durante a irrigação, nem sempre a solução de hipoclorito de sódio atinge todo sistema de canais e a concentração da solução pode, portanto, não desempenhar um papel decisivo.

Mais importante que a concentração da solução irrigante, é a sua capacidade de contato com toda área do canal radicular, sendo que sua ausência resulta em uma região não desinfetada e com remanescente de material orgânico e/ou microrganismos.

O aumento de concentração do hipoclorito de sódio e o tempo de contato com o substrato é diretamente proporcional ao efeito antimicrobiano e à capacidade de dissolução do tecido e inversamente proporcional ao grau de compatibilidade biológica.

A dissolução do tecido pulpar pelo hipoclorito de sódio é fundamental, pois o campo operatório na endodontia é composto por um sistema de canais radiculares sendo que boa parte desse sistema é inacessível aos instrumentos endodônticos (PETERS et al, 2001; MANNAN et al 2001; ROSSI-FEDELE \& DE FIGUEIREDO, 2008; VERSIANI et al, 2011; SOUZA et al, 2012). Ela acaba por ajudar na limpeza dos canais radiculares pela transformação de substâncias insolúveis (tecido pulpar e restos necróticos) em substâncias solúveis como os sabões, cloraminas e sais de aminoácidos além da ação dos sabões produzidos na reação que mantém corpos gordurosos em suspensão (micelas) passíveis de serem aspirados.

Sabendo da toxicidade relacionada ao hipoclorito quando usado sobre altas concentrações, foram estudadas outras formas possíveis de melhorar a eficácia da solução na dissolução do tecido pulpar. O aumento do pH (CHRISTENSEN et al, 2008) e da temperatura das soluções (SPANÓ et al, 2001), a ativação das soluções por ultrassons e tempo de trabalho prolongado (KAMBURIS et al, 2003; ZEHNDER, 2006) são maneiras de otimizar o uso no $\mathrm{NaOCl}$. 
SPANÓ et al (2001) pesquisaram o poder de solvência de tecidos de quatro diferentes concentrações de $\mathrm{NaOCl}$ e concluíram que a concentração era inversamente proporcional à velocidade de solvência dos tecidos, todas as concentrações de hipoclorito de sódio reduziu o pH e a tensão superficial e as concentrações mais elevadas da solução tinha o menor consumo de cloro durante a dissolução do tecido.

Em 2008, ROSSI-FIDELE \& DE FIGUEIREDO testaram a capacidade de dissolução tecidual do hipoclorito de sódio a $4 \%$ em diferentes temperaturas e salientaram a eficiência do aumento de temperatura da solução irrigante, porém apontaram um platô em sua capacidade de solvência dos tecidos quando a temperatura chegou a $60^{\circ} \mathrm{C}$.

IRALA et al (2010) avaliaram a capacidade de dissolução tecidual variando a concentração do hipoclorito de sódio ( $1 \%$ e 2,5\%) e combinando ou não EDTA $17 \%$ à solução irrigante, medindo os valores do $\mathrm{pH}$ das soluções antes e após os experimentos. A combinação de hipoclorito com o EDTA $17 \%$ não foi capaz de dissolver o tecido pulpar enquanto o aumento da concentração aumentou o poder de solvência da solução irrigante frente ao substrato. Os valores do pH nas soluções de hipoclorito de sódio a 1 e 2,5\% antes e após o experimento mantiveram-se constantes.

STOJICIC et al (2010) testaram diferentes concentrações e temperaturas de hipoclorito de sódio utilizando ou não sistemas ultrassônicos para avaliar solvência de tecidos. Os resultados indicaram que o aumento da concentração, da temperatura, do fluxo da substância irrigante e o uso de sistemas ultrassônicos podem melhorar a atuação do hipoclorito em até 50 vezes.

Assim como muitos pesquisadores buscam novas soluções irrigadoras, COBANKARA et al (2010) avaliaram o poder de dissolução tecidual do hipoclorito de sódio 5,25\% comparado com o dióxido de cloro a 13,8\%, uma substância com fortes propriedades antimicrobianas, compatibilidade com tecido vivo e facilidade de uso. Os resultados mostraram semelhança na atuação das soluções testadas, porém salientam a importância de mais pesquisas para os efeitos do dióxido de cloro sobre bactérias dentro dos túbulos dentinários e concentração inibidora mínima. 
Durante a dissolução tecidual há pequena queda no $\mathrm{pH}$ da solução de hipoclorito de sódio, altamente alcalina, devido às reações entre a solução irrigante e o substrato orgânico envolvidos no tratamento endodôntico, provocando liberação de íons cloro. Visando otimizar a solvência de tecidos, JUNGBLUTH et al (2011) adicionaram hidróxido de sódio, outra substância altamente alcalina, ao hipoclorito de sódio afim de manter o pH da solução irrigante durante a dissolução tecidual. Comparando a nova solução à solução de hipoclorito de sódio, os resultados apontaram que as novas soluções tinham os valores do pH inalterados mesmo após os experimentos e provocavam maior perda de peso de tecido.

PALAZZI et al (2012) estudaram a tensão superficial de diferentes soluções irrigantes à base de hipoclorito de sódio (hipoclorito de sódio a 5,25\%, Chlor-Xtra, Hypoclean A e B) e concluíram que as soluções modificadas com surfactantes tinham valores significativamente menores de tensão superficial resultando em maior contato com as paredes da dentina, atingindo mais facilmente áreas não atingidas pelos instrumentos endodônticos, bem como permiti uma maior eficácia antimicrobiana e solvência tecido de polpa.

Muitas pesquisas mostram a relação direta entre o tempo de contato e concentração do hipoclorito de sódio com a sua eficiência na eliminação de determinados microrganismos. No entanto, além de concentrações elevadas serem potencialmente tóxicas para tecidos periapicais (MEHRA et al, 2000; GERNHARDT et al, 2004; BARNHART et al 2005), também há relatos de alterações nas propriedades mecânicas da dentina radicular, tais como diminuição da microdureza e rugosidade após a exposição ao hipoclorito de sódio em concentrações de 2,5\% e 5,25\% (ARI et al, 2004).

Em 1995, SAQUY et al analisaram a microdureza da dentina quando tratada com edta, solução de Dakin ou associação EDTA + solução de Dakin ou água e observaram que a dureza da dentina não é afetada pela água ou pelo líquido de Dakin isoladamente. Todavia, quando a água ou o líquido de Dakin são associados ao EDTA, ocorre a descalcificação da dentina resultando na diminuição da sua microdureza.

Uma solução de $5,25 \%$ de hipoclorito de sódio reduz significativamente os módulos de elasticidade e resistência à flexão da dentina humana comparada ao soro 
fisiológico, enquanto que uma solução a $0,5 \%$ não causa o mesmo impacto sobre a dentina (SIM et al, 2001). Essa diminuição da elasticidade da dentina é causada, provavelmente, pela ação proteolítica do hipoclorito de sódio concentrado sobre a matriz de colágeno da dentina.

BARBOSA et al (1994) estudaram o efeito do hipoclorito de sódio a $5 \%$ e do peróxido de hidrogênio a 35\% sobre a permeabilidade e perda de peso da dentina, constatando o aumento da permeabilidade e a perda de cerca de $14 \%$ do peso seco da dentina em $24 \mathrm{~h}$ quando utilizado o $\mathrm{NaOCl}$.

GUERISOLI et al (1998) analisaram a ação do hipoclorito de sódio em diversas concentrações sobre a estrutura dentinária e concluíram que a dentina mineralizada apresenta perda de massa quando submetida por uma hora à ação do hipoclorito de sódio, senda esta perda estatisticamente semelhante para todas as concentrações e o colágeno dentinário apresenta perda de massa diretamente proporcional à concentração de hipoclorito de sódio, quando submetido a esta solução por uma hora.

PÉCORA et al (1998) estudaram o efeito de redução da tensão superficial de diferentes concentrações de soluções de hipoclorito de sódio na permeabilidade da dentina radicular e concluíram que, comparadas à água, todas as concentrações de hipoclorito de sódio testadas aumentaram a permeabilidade dentinária e atingiram valores de permeabilidade mais elevados quando as soluções de hipoclorito de sódio foram associadas com $0,1 \%$ de lauril dietilinoglicol éter sulfato de sódio.

MOREIRA et al (2009) analisaram as alterações causadas na estrutura da dentina bovina quando tratadas com hipoclorito de sódio a 5,25\% associado ou não a EDTA $17 \%$ e clorexidina $2 \%$ associada ou não à mesma solução quelante concluindo que o hipoclorito de sódio associado ao não causa alterações no colágeno da dentina e os grupos tratados com EDTA $17 \%$ associados ou não com outras substâncias, apresentavam áreas de desmineralização.

Durante 0 tratamento endodôntico, o hipoclorito tem contato direto e constante com tecido conjuntivo de origem mesodérmica: a polpa, rica em compostos orgânicos e a dentina, um tecido conjuntivo altamente diferenciado, constituída por túbulos dentinários, dentina peritubular e intertubular (TEN CATE, 1994). Esta última é composta em cerca de $50 \%$ em peso pela fase mineral, $40 \%$ pela fase orgânica e 
10\% pela fase aquosa, semelhante à formação do osso (WANG \& WEINER, 1998). Noventa por cento do peso dessa fase orgânica é constituída por colágeno, uma proteína, que é quase exclusivamente do tipo I (LINDE \& ROBINS, 1988; GOLDBERG \& TAKAGI, 1993) e é responsável pela formação da estrutura fibrosa tridimensional da matriz dentinária.

Os organoclorados, normalmente encontrados em quantidades muito pequenas na natureza, são gerados pelo contato de substâncias à base de cloro com tecido orgânico composto por cadeias carbônicas, são neurotoxinas, altamente lipofílicas, quimicamente estável e persistente no meio ambiente. Em virtude de sua toxicidade para algumas plantas e insetos, muitos desses compostos organoclorados, produzidos sinteticamente pela ação de cloro elementar sobre hidrocarbonetos derivados do petróleo, tem tido um amplo uso como pesticida. Outros organoclorados são utilizados extensivamente nas indústrias de plásticos e eletrônica.

A ligação carbono-cloro caracteriza-se por ser difícil de romper, e a presença do cloro reduz também a reatividade de outras ligações das moléculas orgânicas. Para muitas aplicações, a falta de reatividade é uma vantagem importante. Porém, essa mesma propriedade significa que, uma vez que os organoclorados tenham entrado no ambiente, eles degradam-se muito lentamente, tendendo, portanto, a se acumular. Além disso, a maioria dos compostos organoclorados é hidrofóbica: eles não se dissolvem facilmente em água, mas são facilmente solúveis em meios semelhantes ao hidrocarboneto, tais como óleos ou tecidos adiposos.

A falta de uma via eficiente para a degradação dos compostos organoclorados em combinação com a sua hidrofobicidade tem levado a seu acúmulo em organismos vivos, incluindo peixes, humanos e outros animais. De fato, todo o planeta, incluindo a totalidade dos seres vivos, sofre uma contaminação de baixo nível por esses produtos químicos. Muitos esforços dos órgãos governamentais e de grupos ambientais nas décadas passadas foram no sentido de documentar essa contaminação e regulamentar o uso dos compostos organoclorados, impedindo que suas concentrações atinjam níveis perigosos, particularmente em nossa dieta alimentar (BAIRD, 2002a). 
Trabalhos mostram a preocupação do impacto da formação dos organoclorados nas redes de tratamento de água (WHO, 1996; IVANCEV-TUMBAS et al, 1999; PICHON, 2000) e do seu uso nos pesticidas na agricultura (ISCAN et al, 2002; KARAMI-MOHAJERI \& ABDOLLAHI, 2011) devido à sua toxicidade.

Embora a carga ambiental de alguns pesticidas organoclorados tenha diminuído lentamente em muitas áreas do mundo devido à restrição de seu uso e produção (SANDERS et al., 1994; BIGNERT et al., 1998; GLYNN et al, 2000), em humanos 0 acúmulo desses ainda geram preocupações (BROUWER et al., 1995; HUISMAN et al., 1995; WEISGLAS- KUPERUS et al., 1995; KOOPMAN-ESSEBOM et al., 1996; ROTHMAN et al., 1997; PATANDIN et al., 1999).

Alguns pesticidas à base de organoclorados conhecidos como poluentes orgânicos persistentes (POPs) são hidrofóbicos, possuem tempo de meia-vida longo e os tendem a acumular no tecido adiposo de animais e humanos (DE VOOGT et al, 1999). Esses POPs podem acumular em moléculas de lipídio de diferentes órgãos do corpo humano envolvidos no metabolismo de carboidratos, proteínas e gorduras como no fígado, pâncreas, camada adiposa, músculos e sangue (MUSSALORAUHAMAA, 1991; HADDAD et al, 2000) alterando a glicólise, gliconeogenese desses órgãos (RAHIMI \& ABDOLLAHI, 2007).

0 cloro $\left(\mathrm{Cl}_{2}\right)$ é o desinfetante mais utilizado no tratamento da água, devido à sua facilidade de utilização, baixo custo e suas eficazes propriedades germicidas. No entanto, o cloro também reage com a matéria orgânica dissolvida de modo a formar subprodutos de desinfecção, tais como trialometanos (clorofórmio) e ácidos haloacéticos. Apesar da desinfecção da água, considerada um dos principais avanços da saúde pública, ser responsável pela diminuição da mortalidade por doenças infecciosas (BOORMAN et al, 1999), alguns produtos são formados quando utilizados certos desinfetantes (cloro, ozônio, dióxido de cloro ou cloraminas) que reagem com matéria orgânica natural durante a produção de água potável (RICHARDSON et al, 2007) e a exposição diária e ao longo da vida com água clorada pode representar um perigo à saúde humana por causa das características carcinogênicas e mutagênicas dos compostos originados.

Estudos epidemiológicos mostram a correlação entre o consumo de água clorada e o aumento do risco para o câncer (CANTOR, 1997; KOIVUSALO et al, 1997, 
TAO et al, 1999) e confirmada por estudos de carcinogenicidade a longo prazo em ratos (HERREN-FREUND \& PEREIRA, 1986). BAIRD (2002b) cita a relação entre a cloração da água com os índices de câncer em várias comunidades dos Estados Unidos. Os problemas de saúde pública causados pela desinfecção da água é atualmente uma grande preocupação em todo mundo.

No corpo humano, há relatos de que os organoclorados podem apresentar riscos à saúde como alteração do metabolismo e das funções vitais celulares resultando em sua morte por necrose ou apoptose in vivo (DATTA et al, 1992; LU et al, 2002; ABDOLLAHI et al, 2004; YUAN et al, 2006; RICHARDSON et al, 2007; SOLTANINEJAD \& ABDOLLAHI, 2009) ou in vitro (BOORMAN et al, 1999; LU et al, 2004; YUAN et al, 2005), toxicidade cutânea, imunotoxicidade (EXON et al, 1987), efeitos reprodutivos e teratogenicidade, a desregulação endócrina e de carcinogenicidade (MOSER et al, 1992; WHO, 1998), sendo hipótese inclusive de afetar a fertilidade do homem (COLBORN et al, 1993; SHARPE \& SKAKKEBAEK, 1993; TOPPARI et al, 1996) e apontado como um dos possíveis responsáveis pelo câncer de mama entre as mulheres (WASSERMANN et al, 1976; MUSSALO-RAUHAMAA et al, 1990; FALCK et al, 1992; WOLFF et al, 1993; DEWAILLY et al, 1994; GÜTTES et al, 1998; HOYER et al, 1998; OLAYA-CONTRERAS et al, 1998).

Diante do exposto acima e considerando o uso comprovado e difundido do hipoclorito de sódio em suas diferentes concentrações durante a terapêutica endodôntica, mais pesquisas precisam ser realizadas com 0 intuito de se verificar 0 potencial risco de sua utilização, devido aos vários produtos tóxicos oriundos da sua reação com os tecidos orgânicos presente no interior do sistema de canais radiculares. 

Proposicãa 

O objetivo do presente trabalho consiste em determinar, por meio da Cromatografia Gasosa acoplada à Espectrometria de Massas, os produtos originados a partir do contato de diferentes concentrações de hipoclorito de sódio com polpa e dentina bovina. 

Materiais e Métodos 

Para facilitar a compreensão da metodologia empregada neste trabalho, este capítulo foi dividido em tópicos, a saber: 1. Substratos Orgânicos; 2. Reagentes; 3. Equipamentos e materiais utilizados; 4. Preparo dos substratos e dos reagentes; 5. Método de extração para análise em Cromatografia Gasosa acoplada em Espectrometria de Massas (CG-MS); 6. Otimização do CG-MS para análise dos produtos gerados pela decomposição do material orgânico pelo $\mathrm{NaOCl} ; 7$. Curva de calibração das amostras.

\section{Substratos Orgânicos}

- Dentina bovina

- Polpa bovina

\section{Reagentes}

Os reagentes utilizados neste trabalho:

- Hipoclorito de Sódio $10 \%$

- H2O Deionizada, Quimis ${ }^{\circledR}$

- Éter Etílico Merck Millipore ${ }^{\circledR}$

\section{Equipamentos e materiais utilizados}

- Cromatógrafo Gasoso QP 2010 Plus Shimadzu ${ }^{\circledR}$ equipado com detector de Massas. Utilizou-se o hélio como gás de arraste. Os cromatogramas foram registrados em computador através do programa GCSolution responsável pela integração dos picos (Figura 1). 


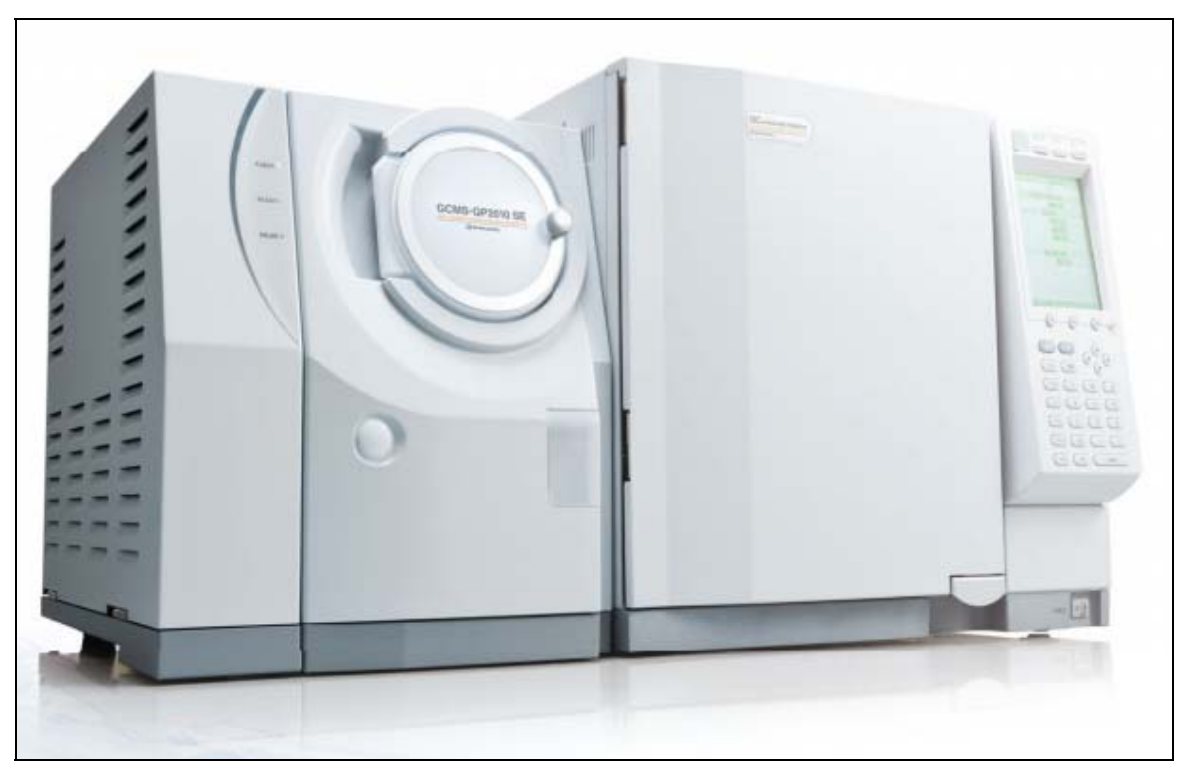

Figura 1. Vista geral do equipamento (Cromatógrafo Gasoso acoplado com Espectrômetro de Massas) utilizado nas análises

- Deionizador de Água, QUIMIS ${ }^{\circledR}$.

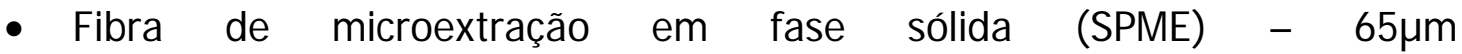
Polidimetilsiloxano/Divinilbenzeno (PDMS/DVB) versão azul SUPELCO ${ }^{\circledR}$ acoplada a holder (Figura 2).

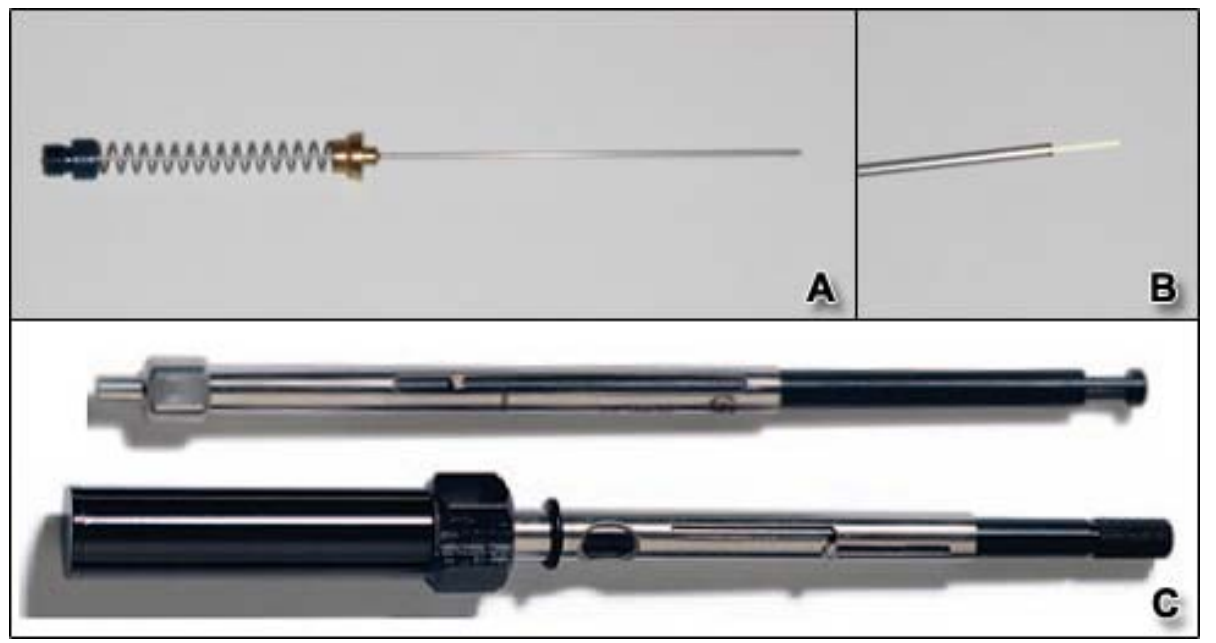

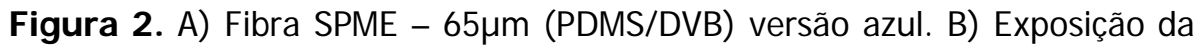
fibra. C) Holder para fibra SPME.

- Balança Analítica Mettler Toledo ${ }^{\circledR}$ AG245

- Tubo plástico transparente com tampa de 1,7ml - Eppendorf ${ }^{\circledR}$. 
- Micro seringa - Hamilton CO. Reno. Nevada Gastight ${ }^{\circledR}$ \# $100^{2}$ - 2 mL.

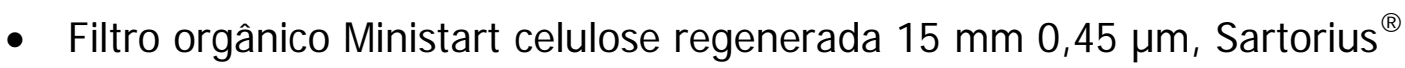

- Ponta diamantada 2068G - KG Sorensen ${ }^{\circledR}$ - Cotia - SP

- Disco diamantado flexível 7010 (mono face) - KG Sorensen ${ }^{\circledR}$ - Cotia - SP

- Micromotor pneumático N270/peça reta - Dabi Atlante ${ }^{\circledR}$ - Ribeirão Preto SP

- Limas Hedstroem 1 a série - Maillefer ${ }^{\circledR}$, Dentsply ${ }^{\circledR}$ - Suíça

- Agitador Magnético sem aquecimento modelo 751 - Fisatom ${ }^{\circledR}$

- Moinho de bola MLW ${ }^{\circledR}$ - Alemanha

\section{Preparo dos Substratos Orgânicos; dos reagentes.}

\section{4a. Preparo dos Substratos Orgânicos}

Os dentes bovinos recém-extraídos tiveram suas coroas separadas das raízes com a ajuda de disco diamantado flexível 7010 mono face (KG Sorensen ${ }^{\circledR}$ ) acoplado em micromotor pneumático N270/peça reta (Dabi Atlante ${ }^{\circledR}$ ). Em seguida, o tecido pulpar foi removido da porção radicular com o auxílio de limas Hedstroem (Dentsply ${ }^{\circledR}$, Maillefer ${ }^{\circledR}$ ), pesado (Balança Analítica Mettler Toledo ${ }^{\circledR}$ AG245), separado em porções de aproximadamente $11 \mathrm{mg}$ e armazenado em geladeira em tubos Eppendorfs ${ }^{\circledR}$ contendo água deionizada $\left(\right.$ Quimis $^{\circledR}$ ) de modo a manter suas características. A porção radicular seccionada teve sua superfície externa preparada com pontas diamantadas 2068G (KG Sorensen ${ }^{\circledR}$ ) para a remoção da camada cementária, seccionada em pequenos fragmentos e em seguida foi triturada em um moinho de bola (MLW ${ }^{\circledR}$ - Alemanha) a fim de obter micropartículas de dentina. Depois de triturada, a dentina bovina foi pesada (Balança Analítica Mettler Toledo ${ }^{\circledR}$ AG245) e separada em porções contendo $30 \mathrm{mg}$ e armazenadas em Eppendorfs ${ }^{\circledR}$ mantidos em temperatura ambiente (Figura 3). 


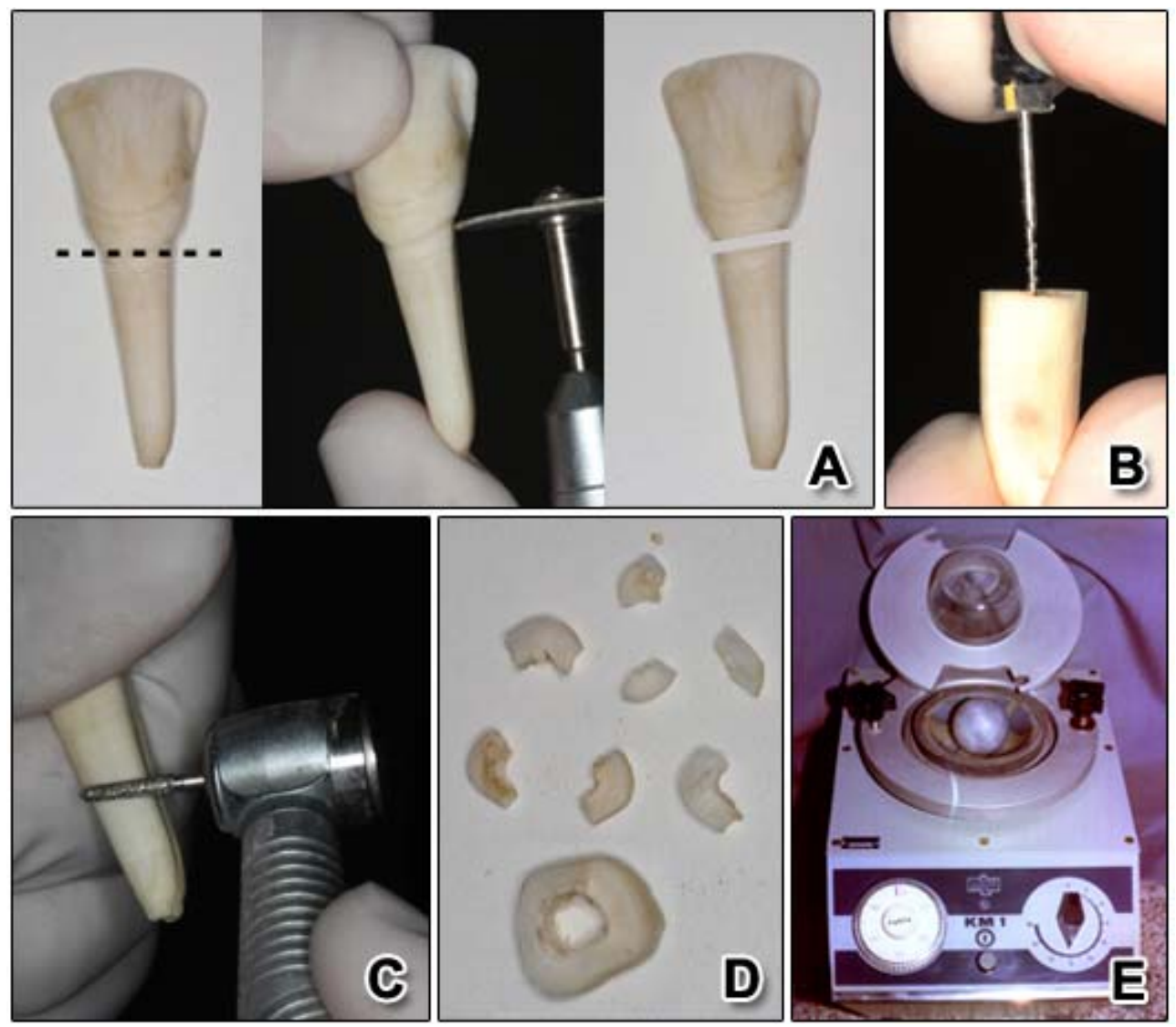

Figura 3. Processo de preparo do substrato orgânico. A) Secção da coroa e raíz do dente bovino. B) Remoção da polpa. C) Preparo da superfície externa da raíz para remoção da camada cementária. D) Fragmentação da raíz para facilitar sua trituração. E) Moinho de bola $\mathrm{MLW}^{\circledR}$ utilizado para triturar os fragmentos de dentina bovina.

\section{4b. Preparo dos reagentes}

As amostras de $\mathrm{NaOCl} 0,5 \%, 2,5 \%$ e 5,25\% foram obtidas a partir da diluição do $\mathrm{NaOCl} 10 \%$ em água deionizada e imediatamente tituladas pelo método da iodometria.

\section{Método de extração para análise em Cromatografia Gasosa acoplada em Espectrometria de Massas (CG-MS)}

\section{5a. Análise das Polpas: extração dos voláteis}

As amostras das polpas previamente pesadas, separas e armazenadas de modo a manter suas características, foram colocadas em recipiente de vidro com tampa contendo $2 \mathrm{ml}$ de $\mathrm{NaOCl}$ nas concentrações descritas no item 4b. Assim foram obtidos os seguintes grupos: 
- Polpa bovina (11 mg) $+\mathrm{NaOCl} 0,5 \%$ (2 ml)

- Polpa bovina (11 mg) $+\mathrm{NaOCl} 2,5 \%$ (2 ml)

- Polpa bovina (11 mg) $+\mathrm{NaOCl} 5,25 \%$ (2 ml)

*Todas as amostras acima foram feitas em triplicatas.

Os recipientes contendo a polpa bovina e a respectiva solução de hipoclorito de sódio foram mantidos sob agitação (agitador magnético sem aquecimento Fisatom ${ }^{\circledR}$ ) para garantir o contato do líquido em toda superfície externa do material orgânico até que pudesse observar a total dissolução do material pelos compostos halogenados. A seguir, ainda sob agitação, a Fibra SPME $(65 \mu \mathrm{m}$ PDMS/DVB SUPELCO ${ }^{\circledR}$ ) acoplada a holder era inserida dentro do recipiente através da membrana existente na tampa do mesmo e exposta pelo tempo de 15 minutos, sem tocar a fase aquosa, com o intuito de efetuar a adsorção dos voláteis gerados pela dissolução do material orgânico em contato com as diferentes concentrações de $\mathrm{NaOCl}$ (Figura 4).

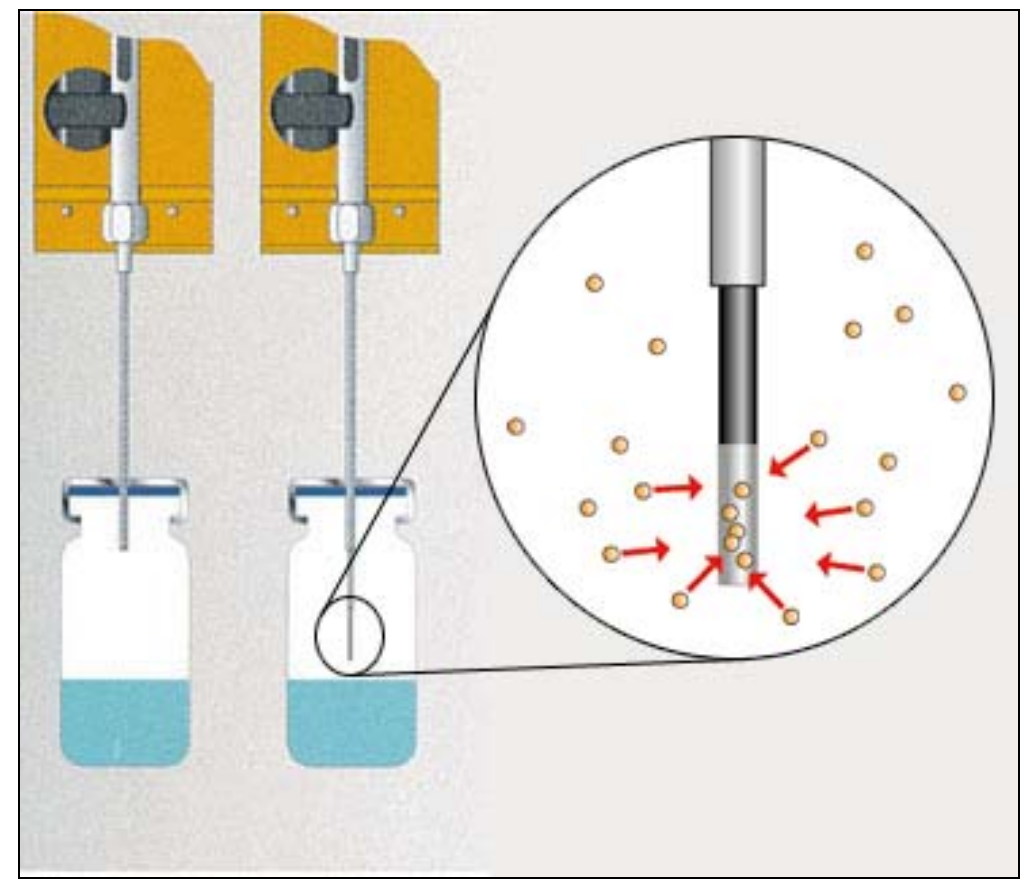

Figura 4. Inserção da fibra SPME dentro do recipiente através da membrana para adsorção dos produtos voláteis gerados pela dissolução do material orgânico em contato com diferentes concentrações de $\mathrm{NaOCl}$. 
Após o tempo de exposição da fibra (15 minutos) a mesma era retirada do recipiente da amostra e imediatamente injetada no CG-MS (permanecendo por 5 minutos) para análise dos compostos voláteis (Figura 5).

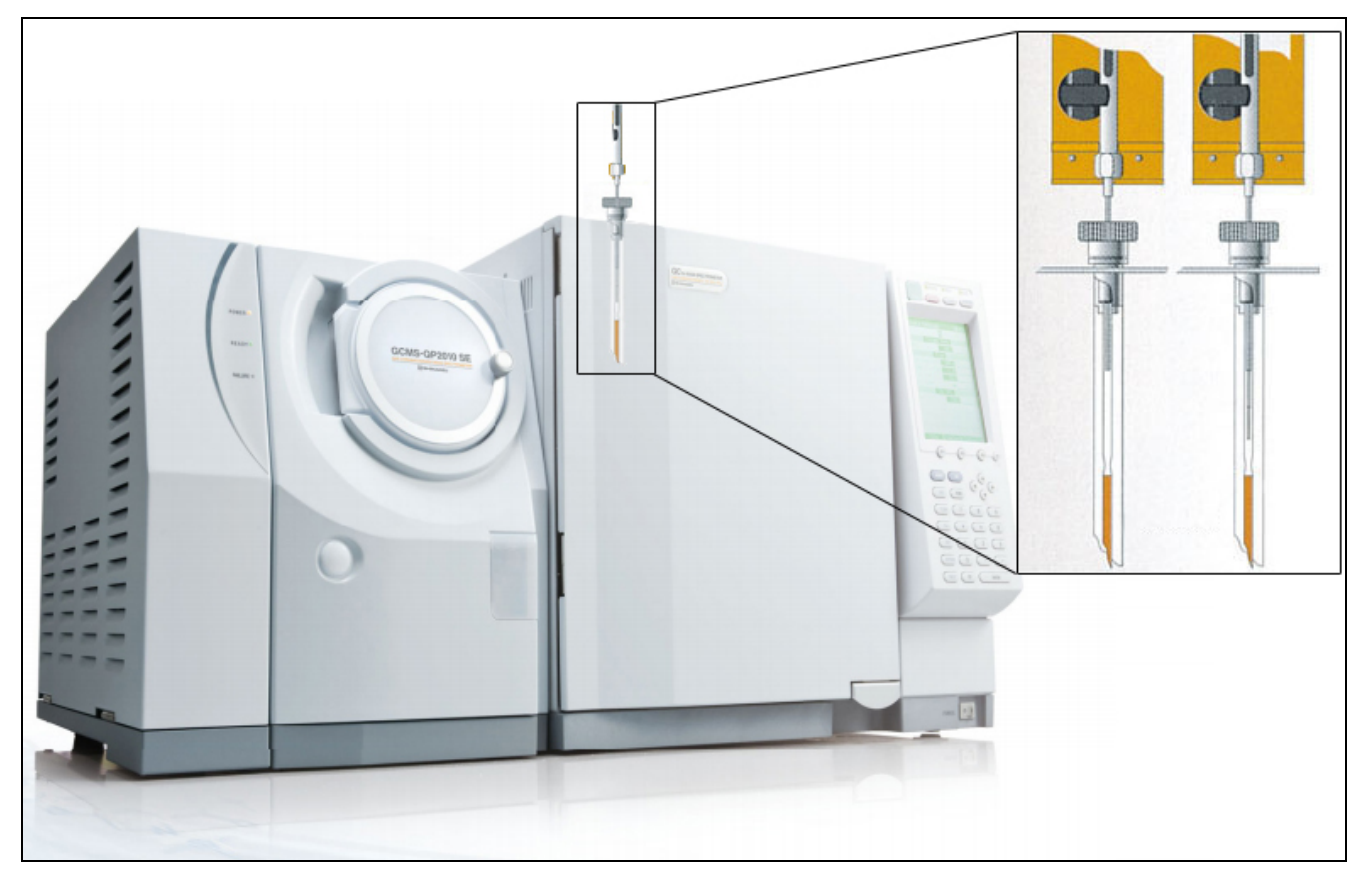

Figura 5. Injeção da fibra impregnada no CG-MS para análise dos compostos.

\section{5b. Análise das Dentinas: extração dos voláteis}

As amostras de dentinas previamente preparada, pesadas e armazenadas de modo a manter suas características, foram colocadas em recipiente de vidro com tampa contendo $2 \mathrm{ml}$ de $\mathrm{NaOCl}$ nas concentrações descritas no item 4b. Assim foram obtidos os seguintes grupos:

- Dentina bovina $(30 \mathrm{mg})+\mathrm{NaOCl} 0,5 \%(2 \mathrm{ml})$

- Dentina bovina (30 mg) $+\mathrm{NaOCl} 2,5 \%(2 \mathrm{ml})$

- Dentina bovina (30 mg) $+\mathrm{NaOCl} 5,25 \%$ (2 ml)

*Todas as amostras acima foram feitas em triplicatas.

Os recipientes contendo a dentina bovina e a respectiva solução de hipoclorito de sódio foram mantidos sob agitação (agitador magnético sem aquecimento - 
Fisatom ${ }^{\circledR}$ ) pelo tempo de 15 minutos para garantir o contato do líquido em toda superfície externa do material orgânico. A seguir, ainda sob agitação, a Fibra SPME $\left(65 \mu \mathrm{m}\right.$ PDMS/DVB SUPELCO ${ }^{\circledR}$ ) acoplada a holder era inserida dentro do recipiente através da membrana existente na tampa do mesmo e exposta pelo tempo de 15 minutos, sem tocar a fase aquosa, com o intuito de efetuar a adsorção dos voláteis gerados pela dissolução do material orgânico em contato com o $\mathrm{NaOCl}$ em suas diferentes concentrações.

Após o tempo de exposição da fibra (15 minutos) a mesma era retirada do recipiente da amostra e imediatamente injetada no CG-MS (permanecendo por 5 minutos) para análise dos compostos voláteis gerados.

\section{5c. Análise das Polpas e Dentinas - fase aquosa}

Para análise da fase aquosa das polpas e dentinas foi utilizado o mesmo protocolo. Deste modo, após a remoção das fibras para a análise dos compostos voláteis, foi feita a extração da solução final obtida por meio de éter etílico puro, padronizando-se a mistura de $2 \mathrm{ml}$ da solução $+2 \mathrm{ml}$ de éter (Merck Millipore ${ }^{\circledR}$ ) e mantendo sob agitação (agitador magnético sem aquecimento - Fisatom ${ }^{\circledR}$ ) durante 5 minutos para assegurar a mistura dos líquidos. Seguida a agitação, a fase suspensa da mistura era aspirada com Micro seringa (Hamilton CO. Reno. Nevada Gastight ${ }^{\circledR}$ \# $100^{2}$ - $2 \mathrm{~mL}$ ) separando o éter da fase aquosa da solução obtida. 0 éter, contendo 0 material resultante da interação química dos compostos orgânicos da dentina ou polpa com o $\mathrm{NaOCl}$ nas suas diferentes concentrações, era filtrado (Filtro orgânico

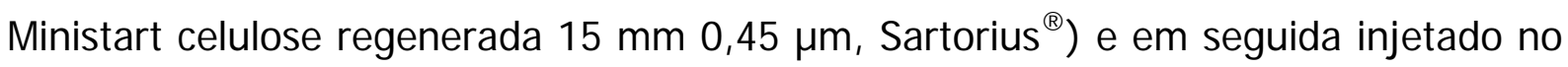
CG-MS para análise da fase aquosa das amostras.

\section{Otimização do CG-MS para análise dos produtos gerados pela decomposição do material orgânico pelo $\mathrm{NaOCl}$}

A temperatura foi variada a fim de obter a melhor separação possível dos produtos de decomposição das matérias orgânicas em $\mathrm{NaOCl}$. Dentre as condições avaliadas, a resolução cromatográfica ideal está apresentada abaixo: 
Temperatura inicial do forno: $40^{\circ} \mathrm{C}$

Temperatura do Injetor: $250^{\circ} \mathrm{C}$

Rampa:

$40^{\circ} \mathrm{C}$ por 2,5 minutos $>130^{\circ} \mathrm{C}$ (velocidade $35^{\circ} \mathrm{C} / \mathrm{min}$ ) $>145^{\circ} \mathrm{C}$ por 4 minutos

Controle de Fluxo - Velocidade Linear

-Pressão: 49,7 KPa

- Fluxo Total: $14 \mathrm{ml} / \mathrm{min}$

- Fluxo da coluna: $1 \mathrm{ml} / \mathrm{min}$

- Modo Injeção Split (relação 10)

\section{Curva de calibração das amostras}

Realizou-se a padronização do método com a obtenção da curva de calibração para: 
> Controle 1 (Fibra SPME): assim que removida do seu invólucro, a fibra foi injetada no CG-MS para análise. A linha em azul constante no valor 0 presente na ordenada da Figura 6 indica que não houve detecção de qualquer substância na fibra SPME que pudesse alterar resultados deste trabalho.

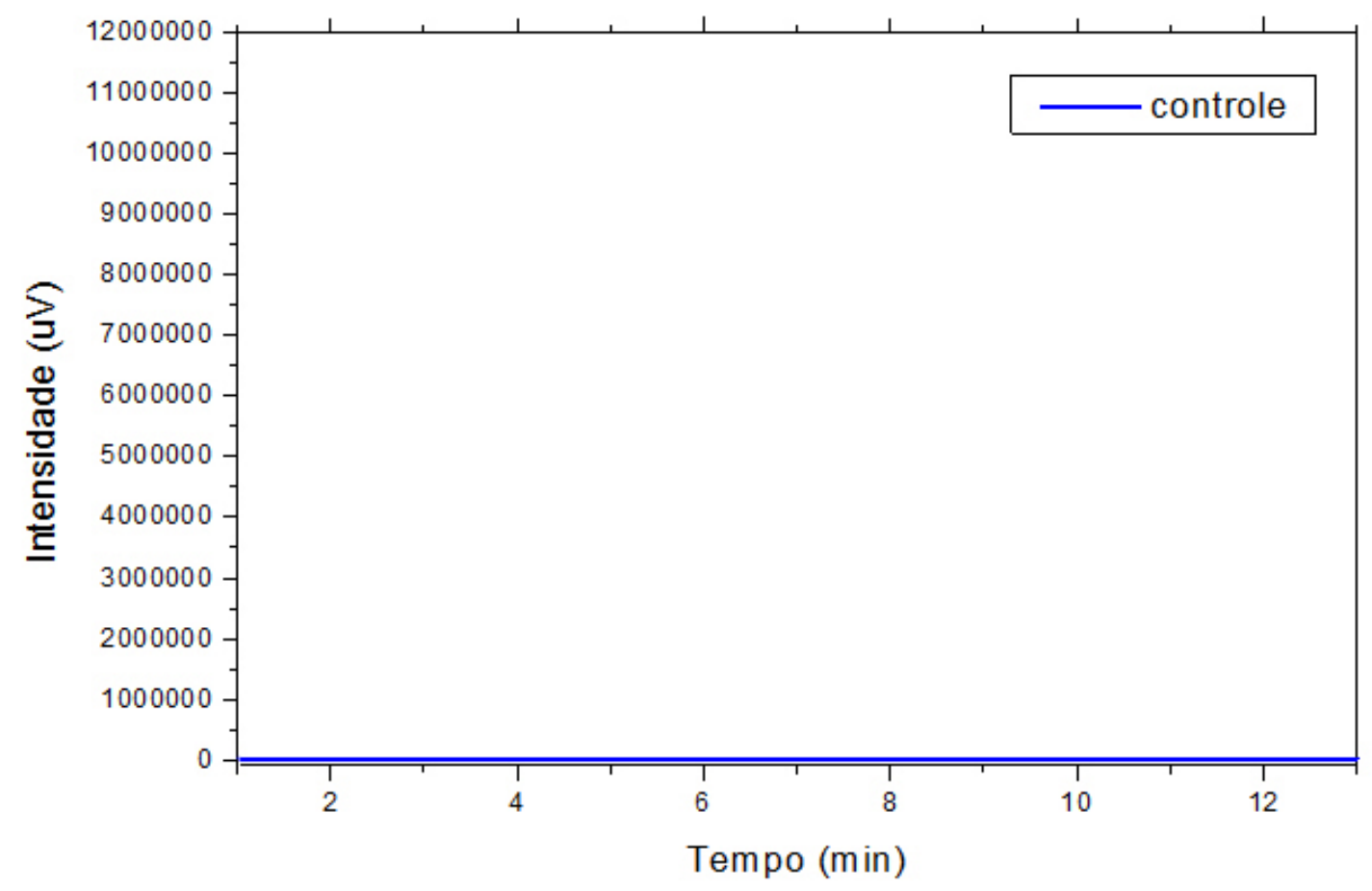

Figura 6. Análise imediata da fibra em CG-MS antes do contato com qualquer reagente ou produto. 
> Controle 2 ( $\mathbf{N a O C l} 5, \mathbf{2 5} \%$ ): a fibra foi inserida em ambiente fechado contendo $\mathrm{NaOCl}$ a $5,25 \%$, exposta por 15 minuto sem contato com 0 líquido e em seguida foi injetada no CG-MS para análise. As pequenas oscilações que aparecem nos resultados expressos na Figura 7 estão dentro do padrão de desvio, concluindo que o $\mathrm{NaOCl} 5,25 \%$ não possui qualquer substância que pudesse alterar os resultados deste trabalho.

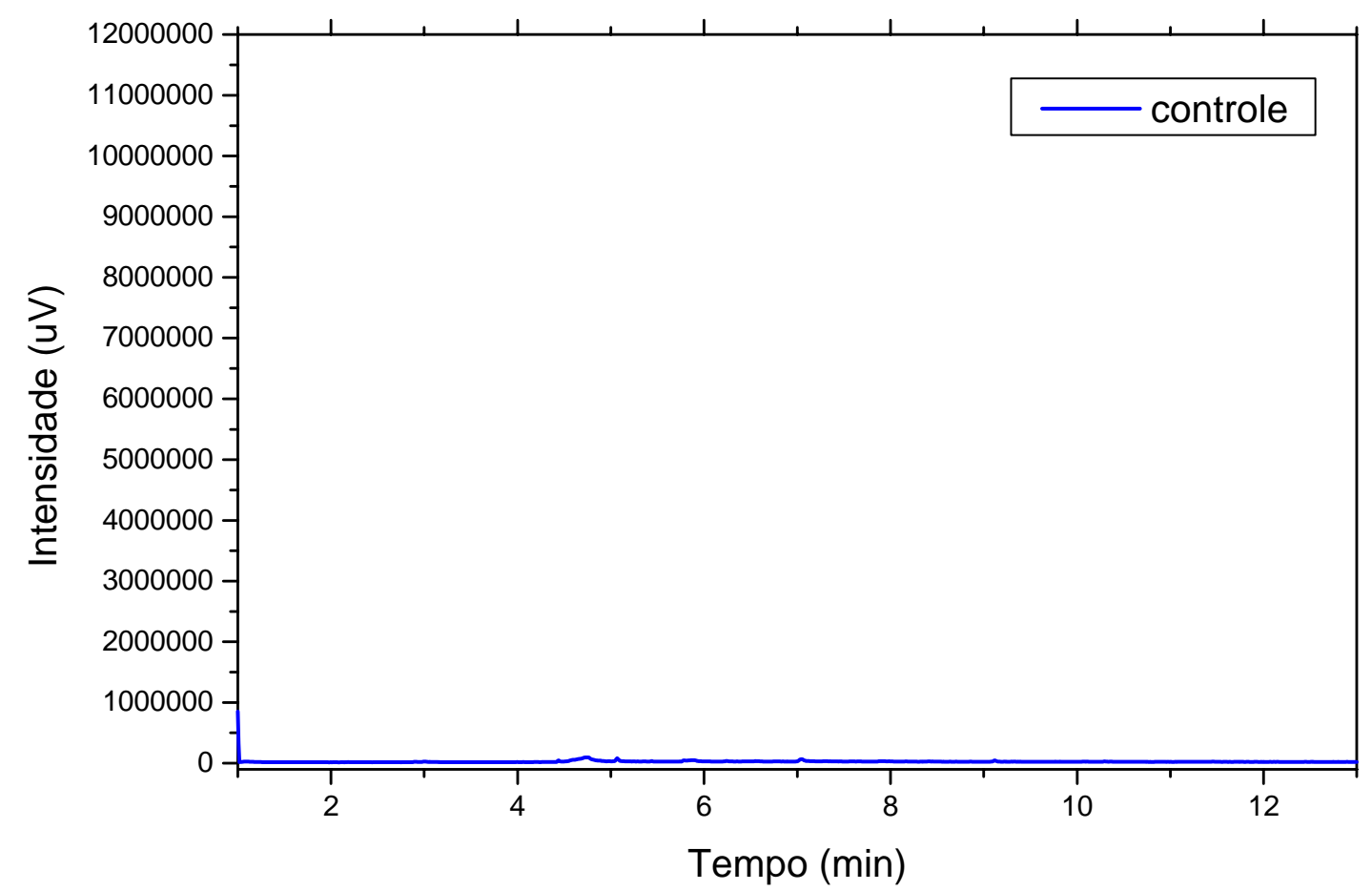

Figura 7. Análise imediata dos produtos volatilizados após exposição da fibra apenas ao $\mathrm{NaOCl}$ a $5,25 \%$. 
Controle 3 (polpa bovina): a fibra foi inserida em ambiente fechado contendo polpa bovina, exposta por 15 minuto sem contato com a amostra e em seguida foi injetada no CG-MS. A linha em azul constante no valor 0 presente na ordenada da Figura 8 indica que não houve detecção de qualquer substância na polpa bovina que pudesse alterar resultados deste trabalho.

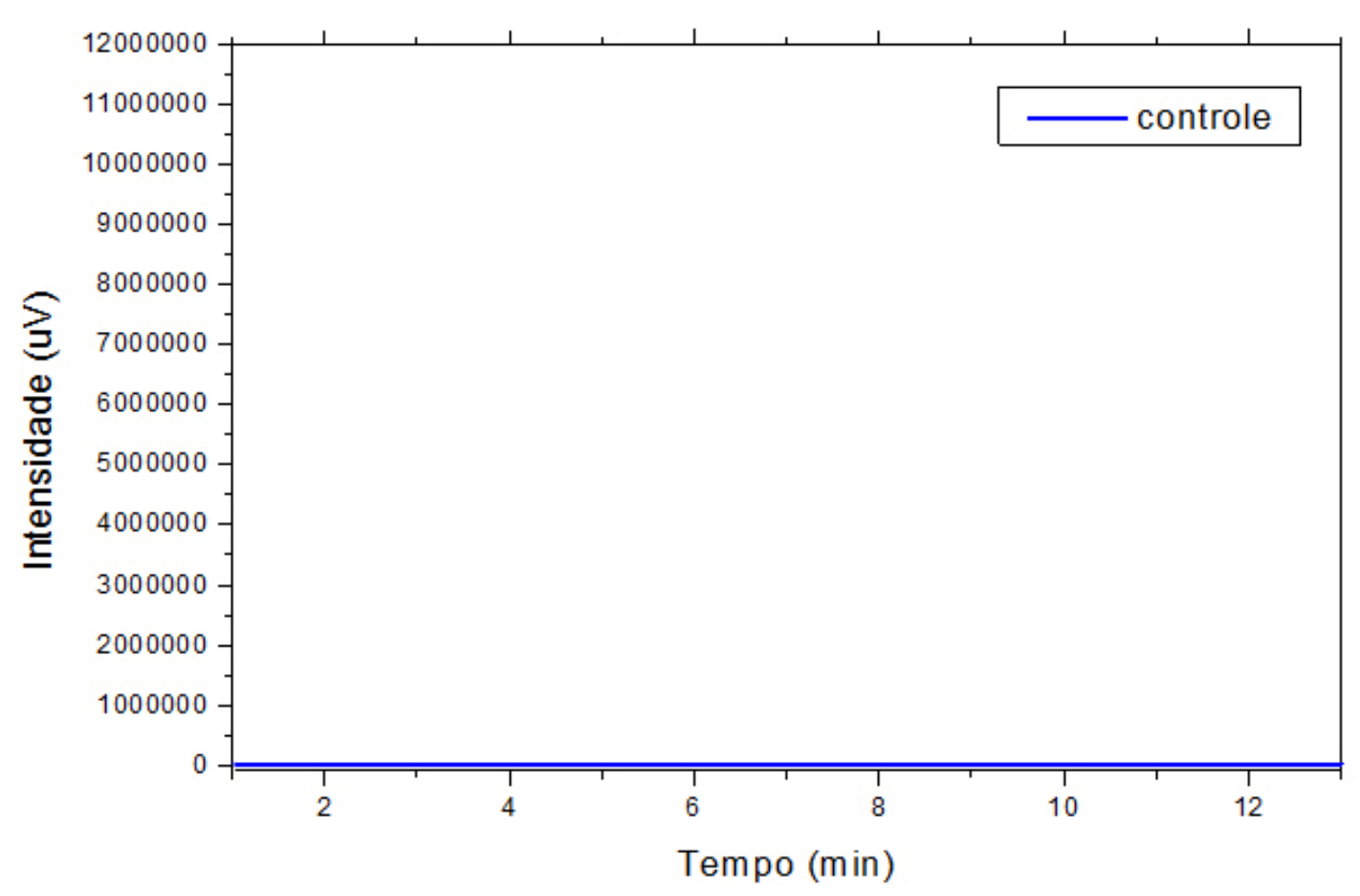

Figura 8. Análise imediata dos produtos volatilizados após exposição da fibra apenas à polpa bovina. 
Controle 4 (dentina bovina): a fibra foi inserida em ambiente fechado contendo dentina bovina, exposta por 15 minuto sem contato com a amostra e em seguida foi injetada no CG-MS (Figura 9). A linha em azul constante no valor 0 presente na ordenada da Figura 8 indica que não houve detecção de qualquer substância na dentina bovina que pudesse alterar resultados deste trabalho.

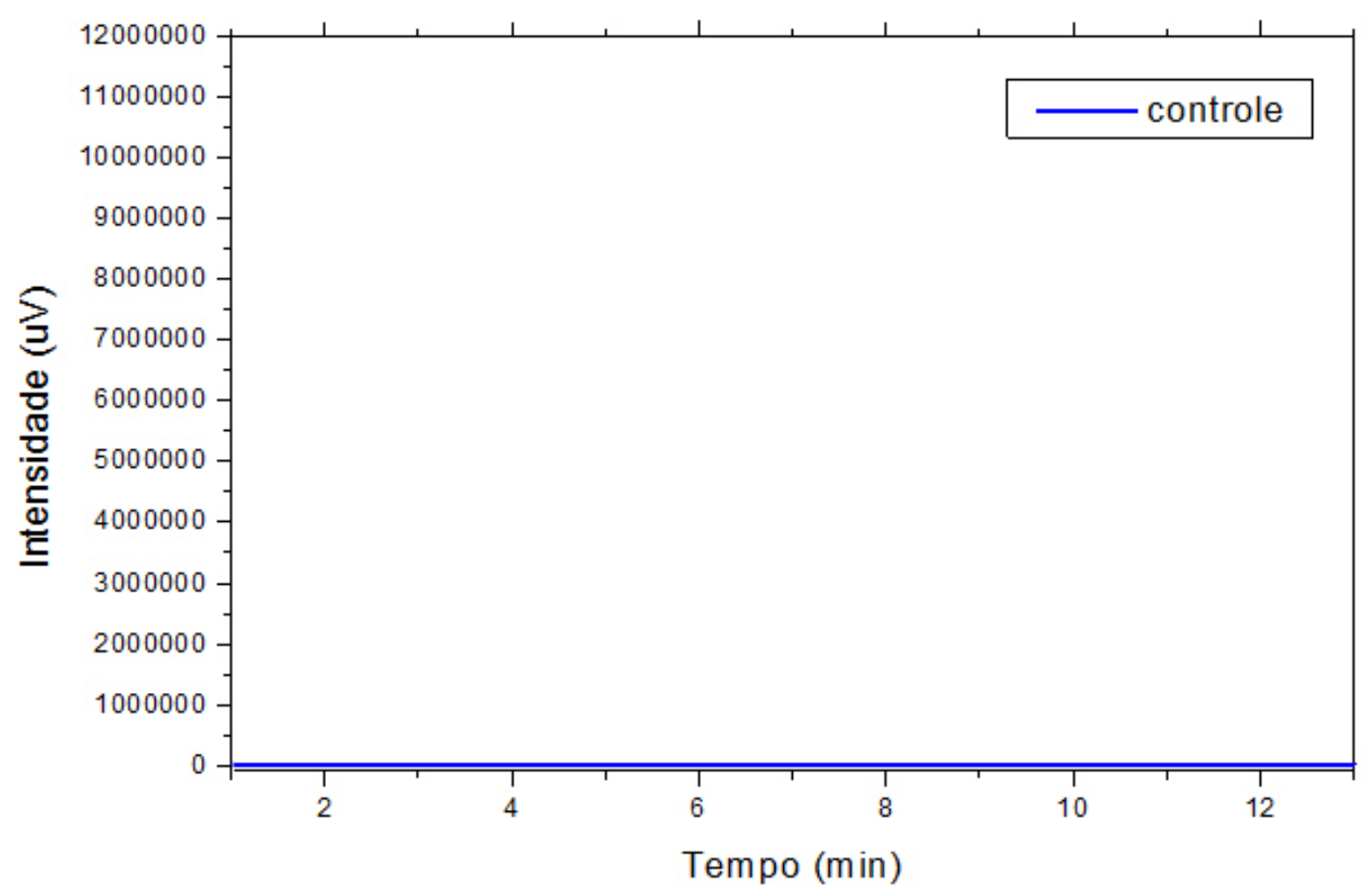

Figura 9. Análise imediata dos produtos volatilizados após exposição da fibra apenas à dentina bovina. 
Controle 5 (éter etílico): a fibra foi inserida em ambiente fechado contendo éter etílica, exposta por 15 minuto sem contato com o líquido e em seguida foi injetada no CG-MS (Figura 10). O pico no tempo de retenção 1,6 min. refere-se à identificação do éter etílico volatilizado adsorvido pela fibra, não apresentando qualquer outra substância ou produto que pudesse alterar os resultados deste trabalho.

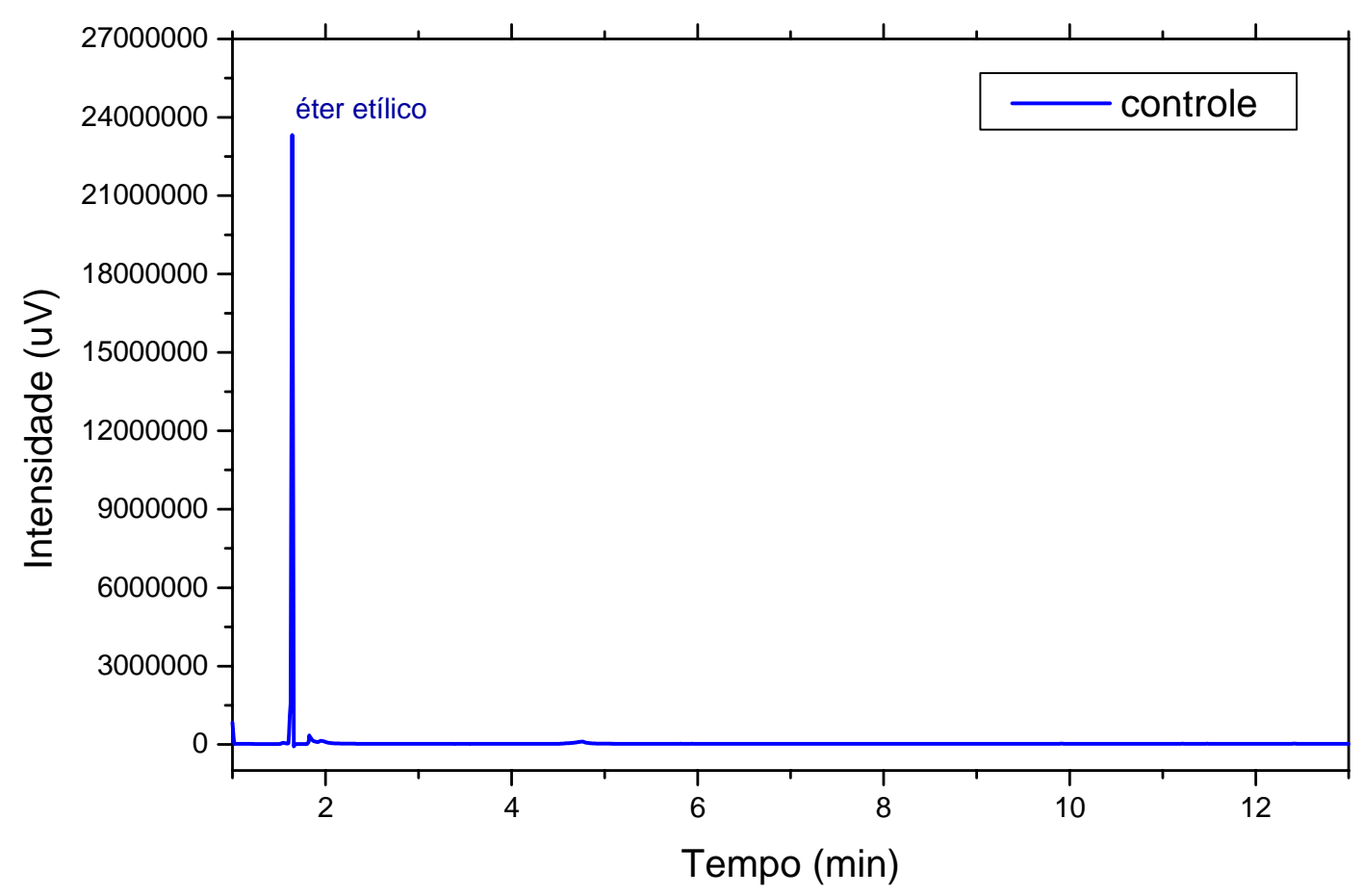

Figura 10. Análise em CG-MS do solvente éter etílico utilizado para as extrações em fase líquida. 

Resultados 

Os resultados cromatográficos dos produtos originados pelo contato do $\mathrm{NaOCl}$ com o material orgânico (polpa/dentina) obtidos com a submissão das amostras no Cromatógrafo Gasoso acoplado ao Espectrômetro de Massas (CG-MS), serão expressos da seguinte forma: 1. Extração dos voláteis; 2. Extração da fase aquosa; 3. Análise das áreas dos picos obtidos na cromatografia gasosa dos compostos voláteis (relação concentração do hipoclorito de sódio e produtos gerados).

\section{Extração dos voláteis}

\section{1a. Dentina}

O resultado obtido por meio do Cromatógrafo Gasoso a qual foi submetida a extração dos voláteis do composto originado pelo contato das diferentes concentrações do $\mathrm{NaOCl}$ com a dentina bovina está ilustrado na Figura 11.

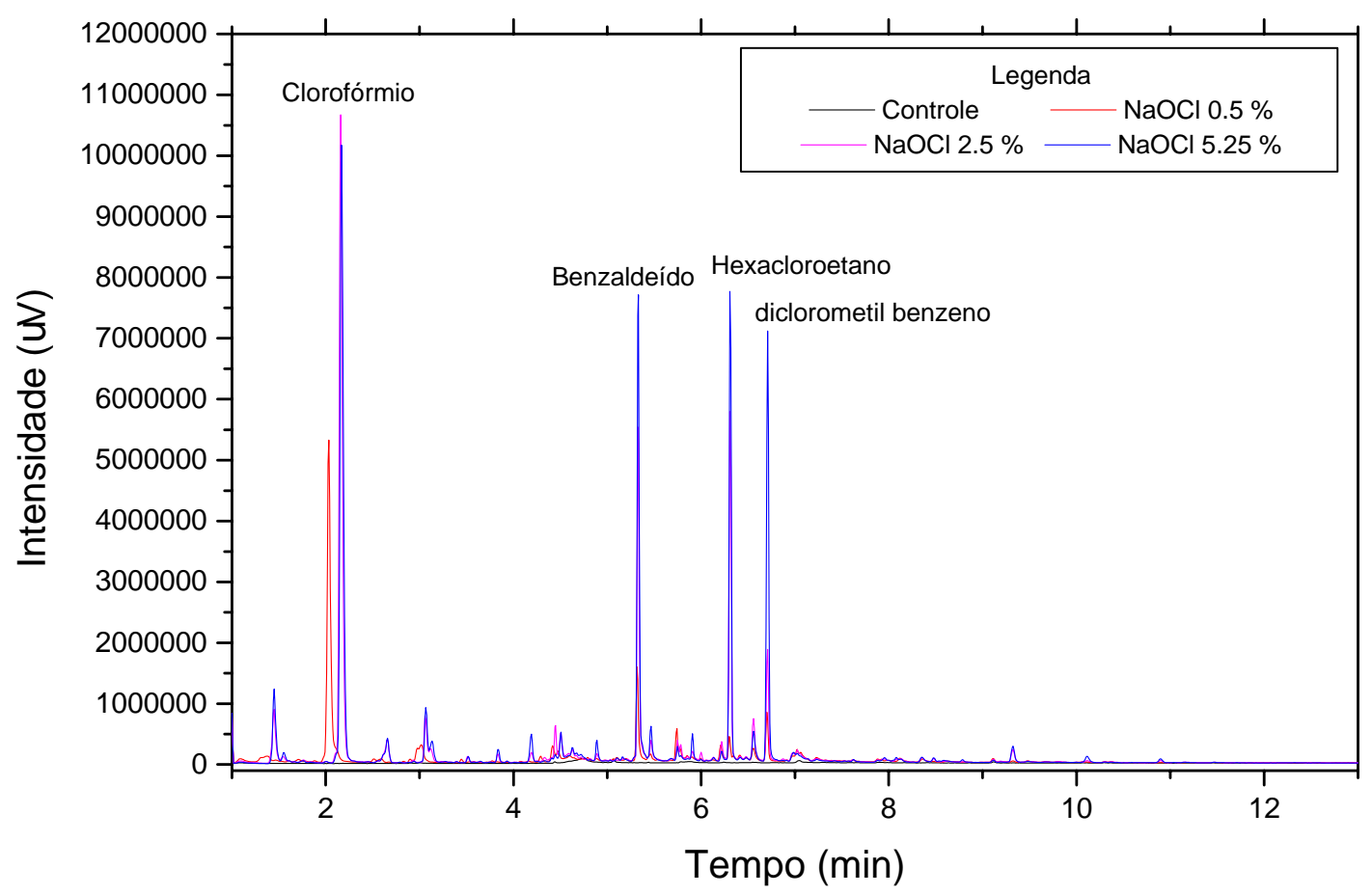

Figura 11. Análise cromatográfica inicial dos produtos formados na reação entre $\mathrm{NaOCl}$ e dentina bovina. 
Observa-se na Figura 11, um pico com tempo de retenção (TR) de 2,15 min., detalhado na Figura 12, o qual se refere à geração de clorofórmio, de massa carga $(m / z)=83,47$, que é um organoclorado. 0 espectro de massas deste pico na figura 11 pode ser visto com detalhe na Figura 13. A estrutura molecular do produto clorofórmio pode ser visto na Figura 14.

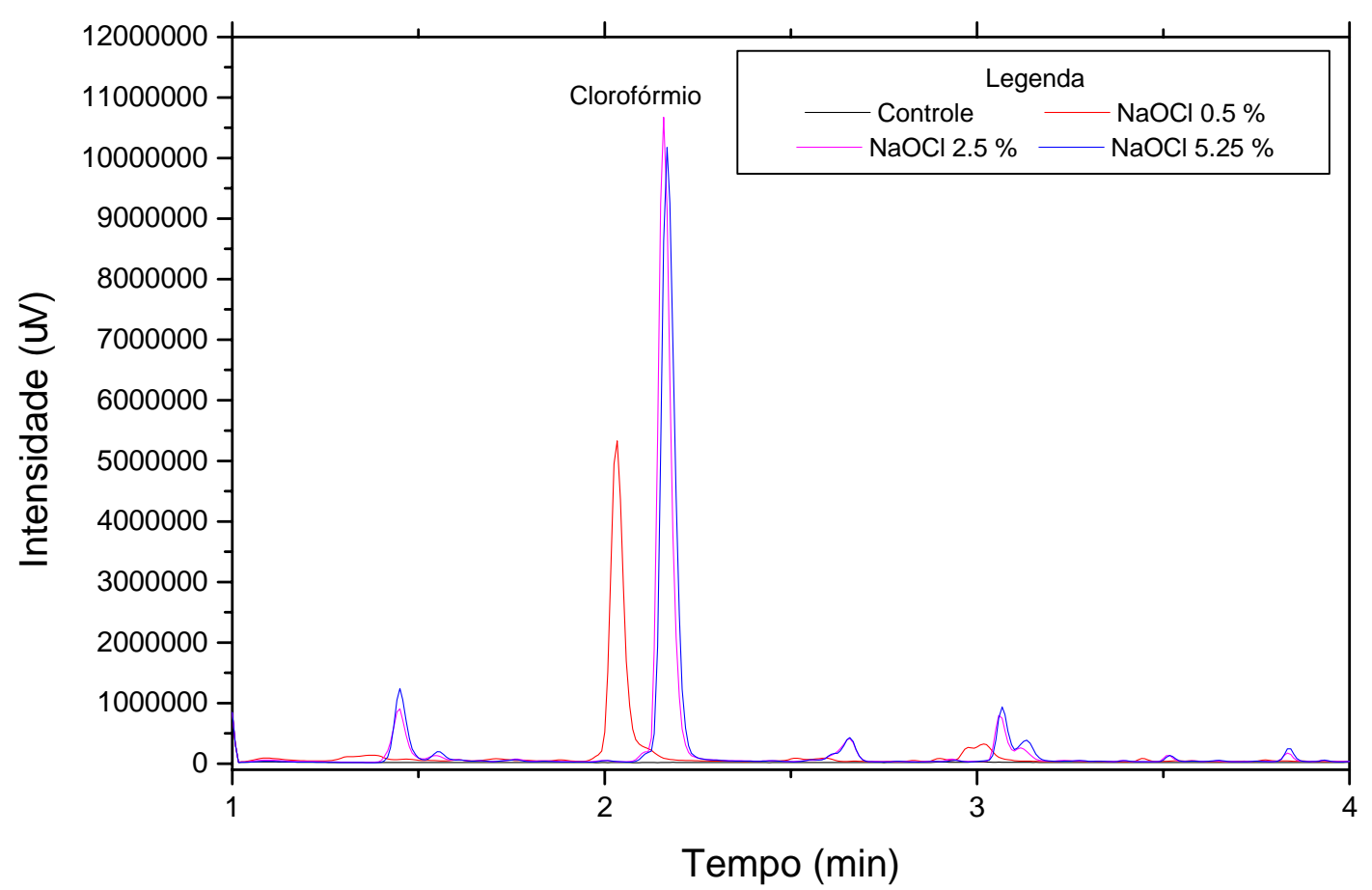

Figura 12. Zoom de 1 - 4 min da análise imediata dos produtos voláteis formados na reação entre $\mathrm{NaOCl} /$ dentina bovina.

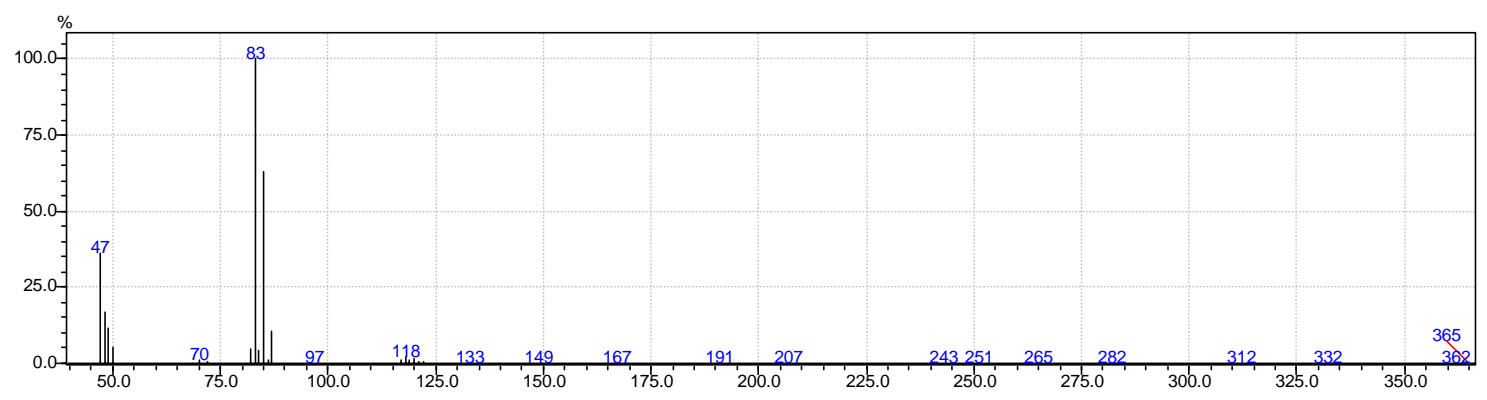

Figura 13. Espectro de massas referente ao pico com $T R=2,15$ min. da Figura 12, correspondendo ao clorofórmio, obtido após dessorção da fibra. 


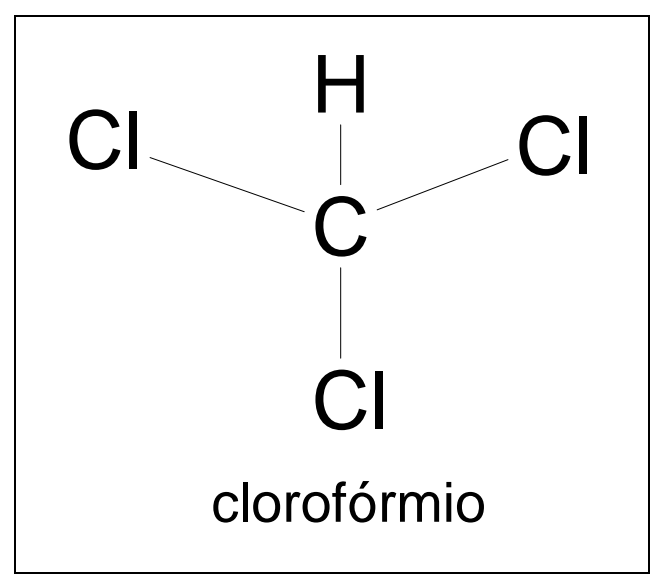

Figura 14. Ilustração da estrutura molecular do organoclorado clorofórmio.

O segundo pico da Figura 11, detalhado na Figura 15, correspondente ao TR de 5,32 min., refere-se a deteç̧ão de benzaldeído de $\mathrm{m} / \mathrm{z}=106,77,51$. Seu espectro de massas pode ser observado na Figura 16 e sua estrutura molecular na Figura 17.

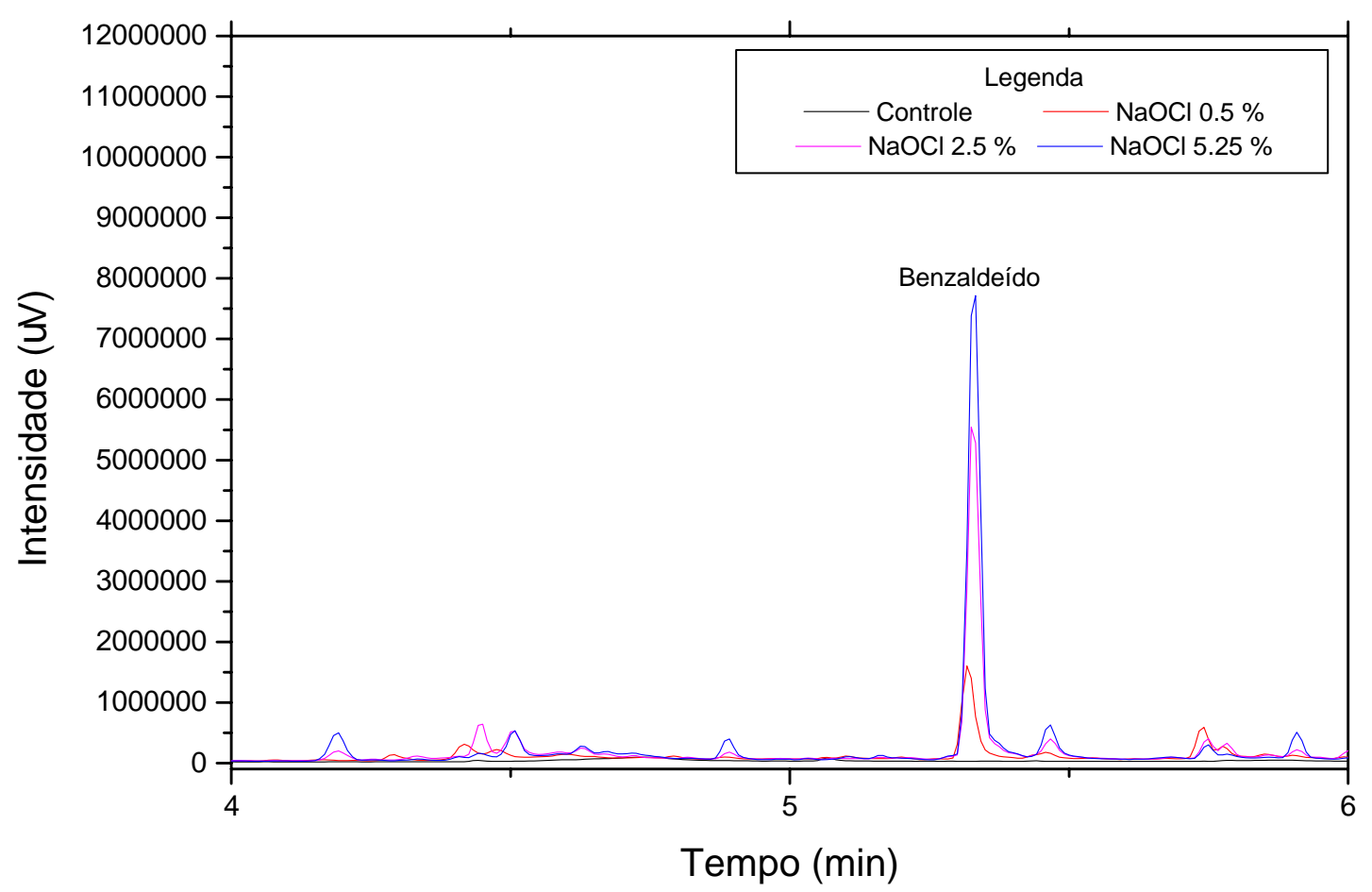

Figura 15. Zoom de 4 - $6 \mathrm{~min}$ da análise imediata dos produtos voláteis formados na reação entre $\mathrm{NaOCl}$ e a dentina bovina. 


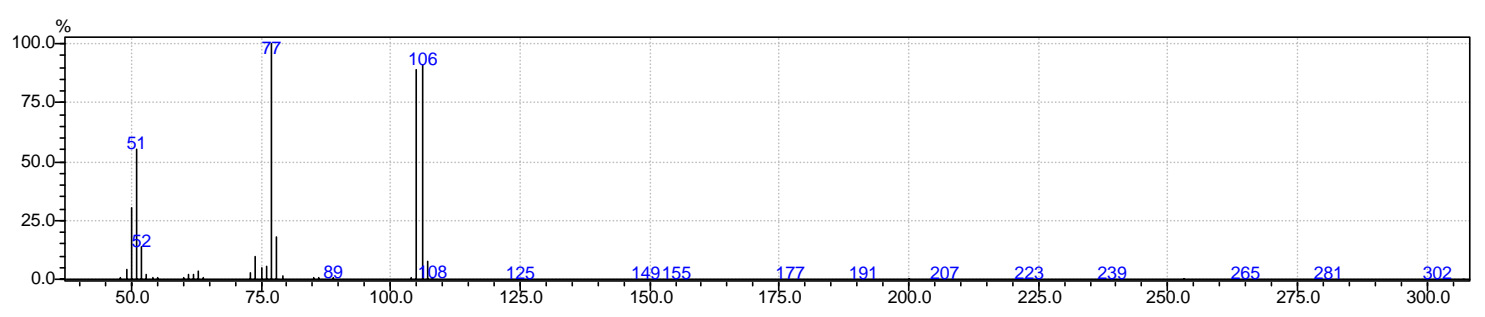

Figura 16. Espectro de massas referente ao pico com $T R=5,32 \mathrm{~min}$. da figura 15 , correspondendo ao benzaldeído, obtido após dessorção da fibra.

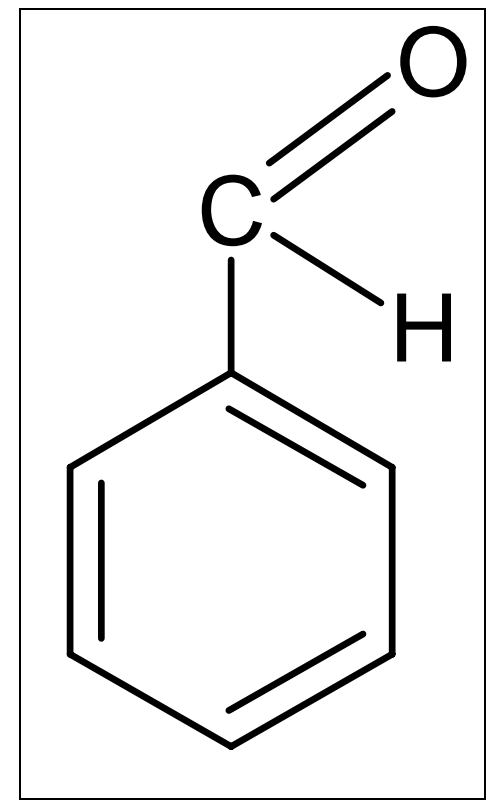

Figura 17. Ilustração da estrutura molecular do benzaldeído.

A seguir, observa-se a presença de um terceiro pico com a $\operatorname{TR}=6,30 \mathrm{~min}$., com imagem maximizada na Figura 18, que aponta a detecção de outro organoclorado, o hexacloroetano de $\mathrm{m} / \mathrm{z}=201,166,117,94$ e seu espectro de massas pode ser observado na Figura 19. A estrutura molecular e tridimensional está ilustrada na figura 20. 


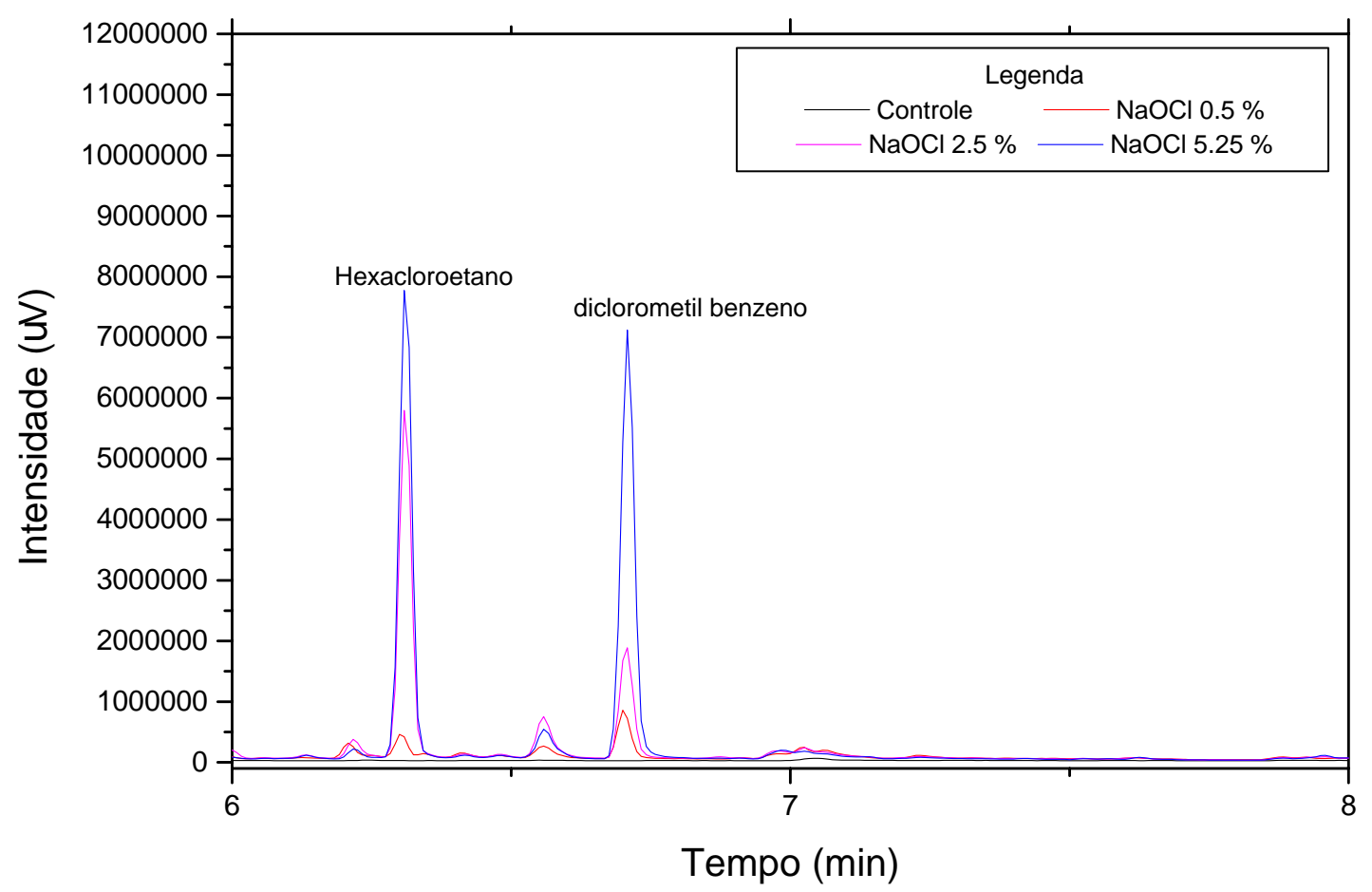

Figura 18. Zoom de 6 - 8 min da análise imediata, dos produtos voláteis formados na reação entre $\mathrm{NaOCl}$ e a dentina bovina.

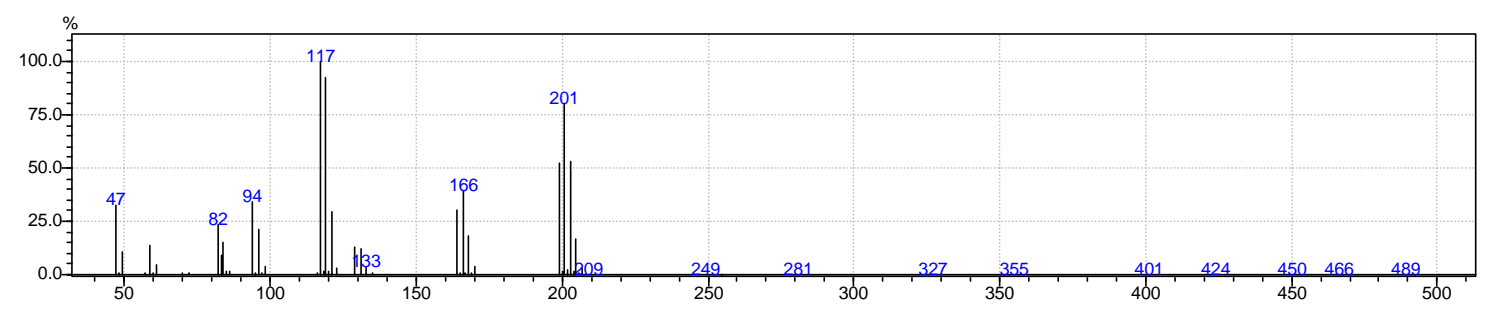

Figura 19. Espectro de massas referente ao pico com $T R=6,3 \mathrm{~min}$. da Figura 18, correspondendo ao hexacloroetano, obtido após dessorção da fibra.

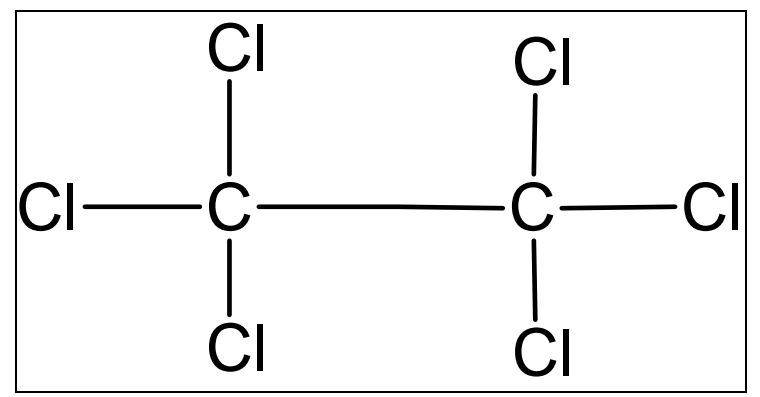

Figura 20. Ilustração da estrutura molecular do hexacloroetano. 
Um último pico de maior evidência ilustrado ainda na Figura 11, detalhado na Figura 18 em maior aumento, retido no tempo $T R=6,7$ min corresponde a mais um organoclorado resultante do contato do $\mathrm{NaOCl}$ com a matéria orgânica da dentina bovina: o diclorometilbenzeno. 0 organoclorado formado possui $\mathrm{m} / \mathrm{z}=125,89$, 63 , seu espectro de massas e sua estrutura molecular estão ilustrados nas figuras 21 e 22 , respectivamente.

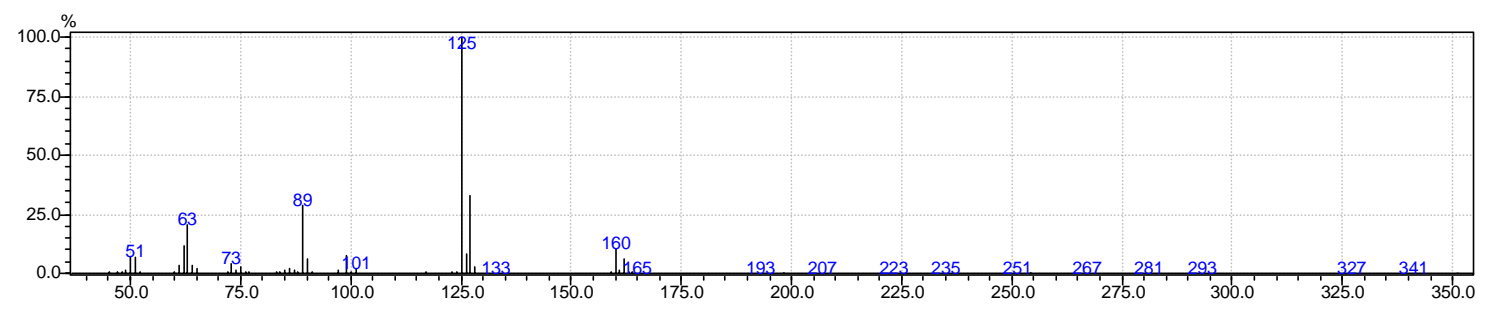

Figura 21. Espectro de massas referente ao pico com $T R=6,7$ min. da Figura 18 correspondendo ao diclorometilbenzeno, obtido após dessorção da fibra.

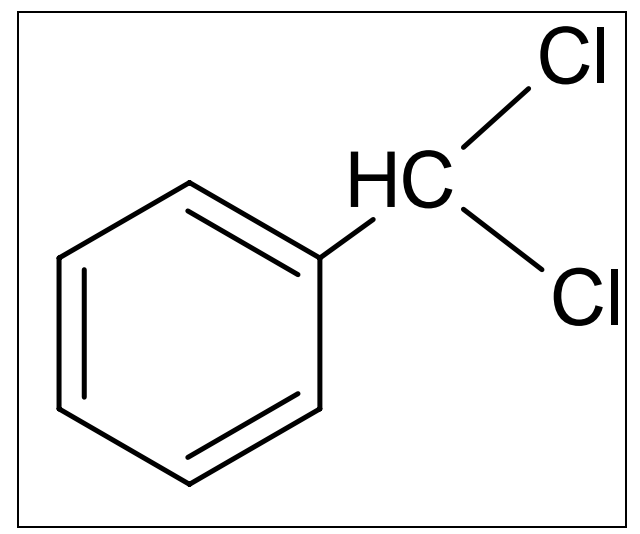

Figura 22. Ilustração da estrutura molecular do diclorometilbenzeno.

\section{1b. Da Polpa}

O resultado obtido por meio do Cromatógrafo Gasoso a qual foi submetido a extração do composto originado pelo contato das diferentes concentrações do $\mathrm{NaOCl}$ com a polpa bovina está ilustrado na Figura 23. 


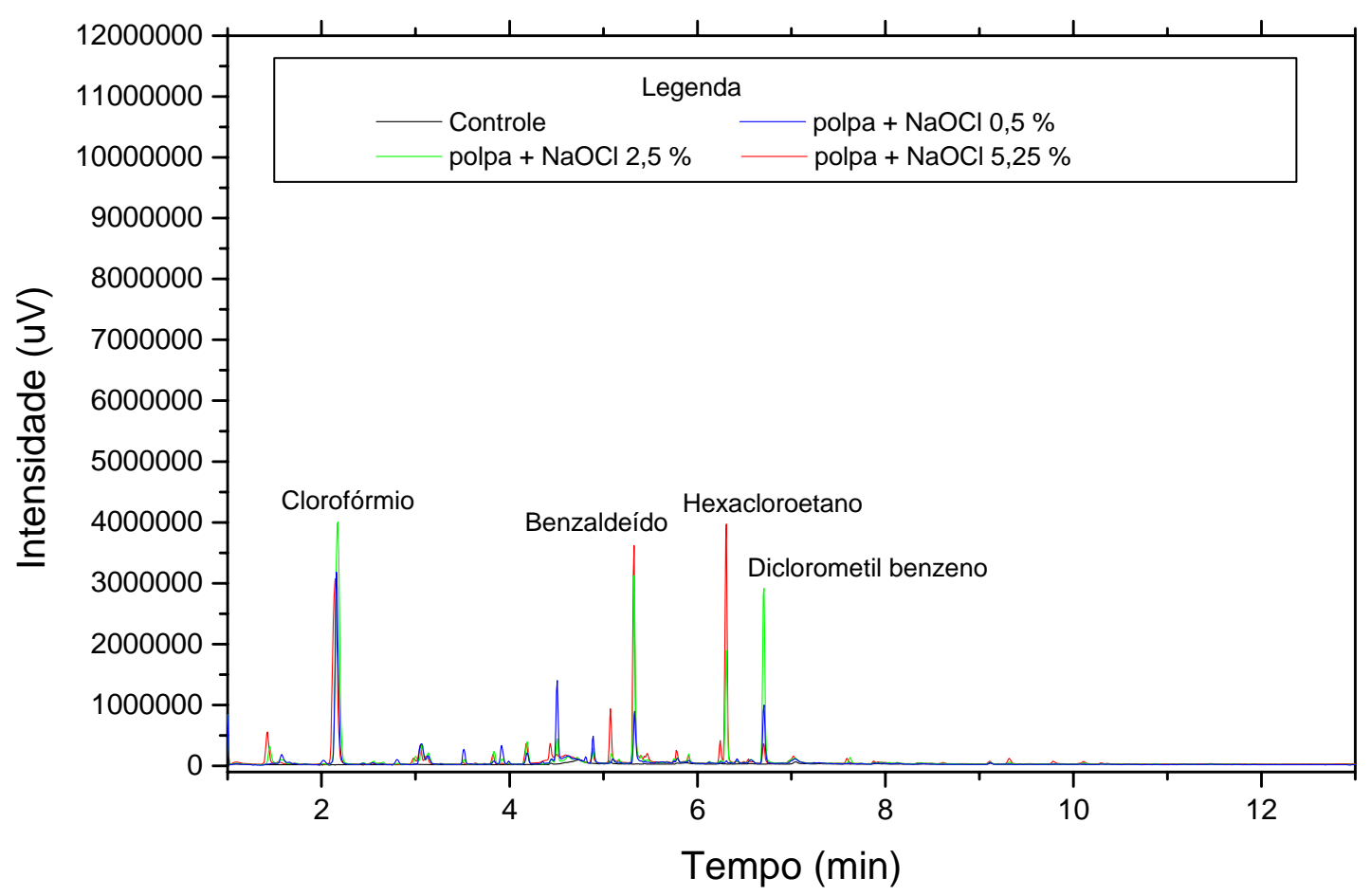

Figura 23. Análise imediata dos produtos voláteis formados na reação entre $\mathrm{NaOCl}$ e polpa bovina.

A Figura 23 foi desmembrada mantendo os valores da ordenada e diminuindo 0 intervalo apresentado nas abscissas, maximizando os picos presentes como demonstram as Figuras 24, 25 e 26. 


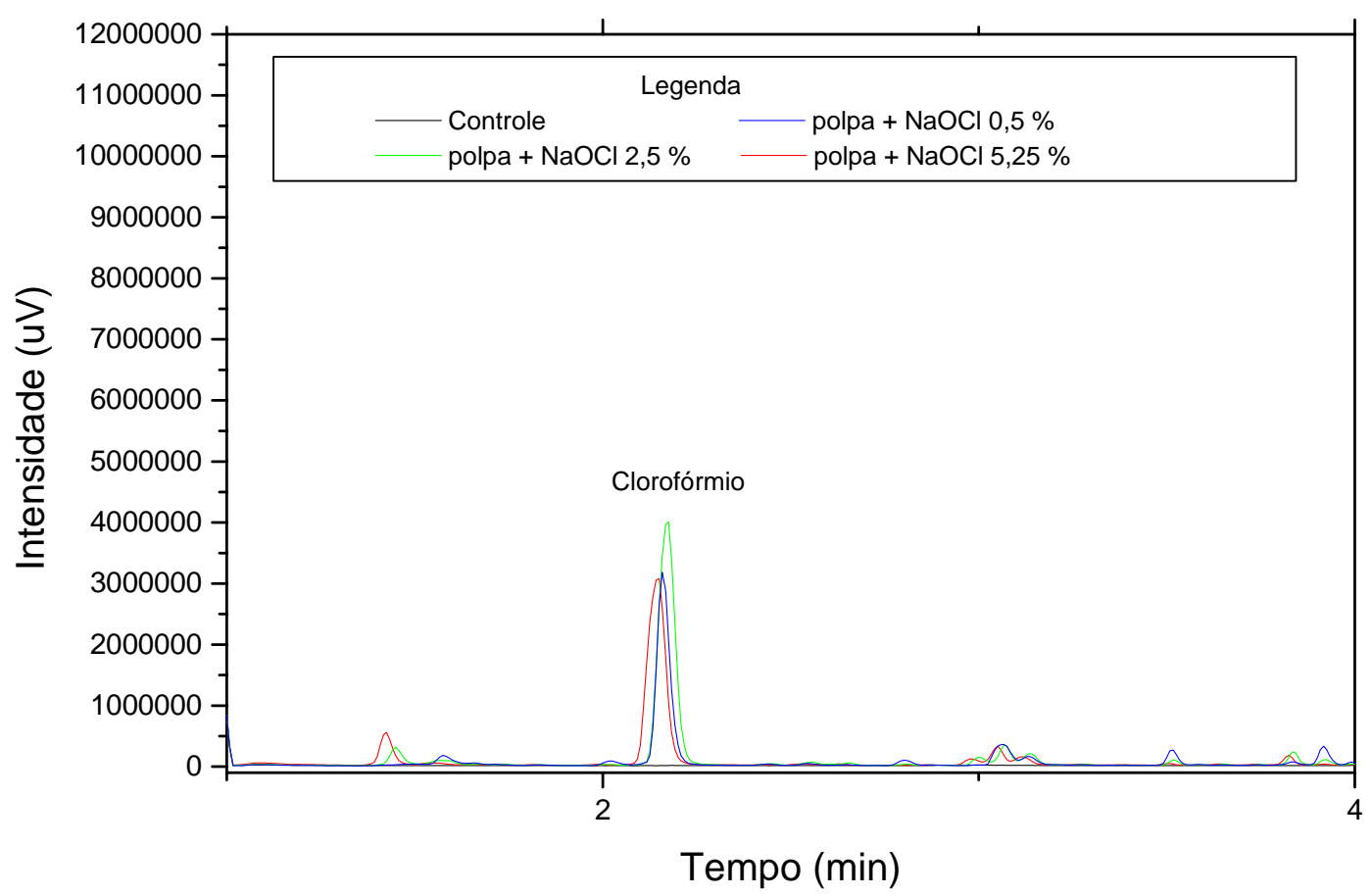

Figura 24. Zoom de 1 - 4 min da análise imediata dos produtos voláteis formados na reação entre $\mathrm{NaOCl} /$ polpa bovina.

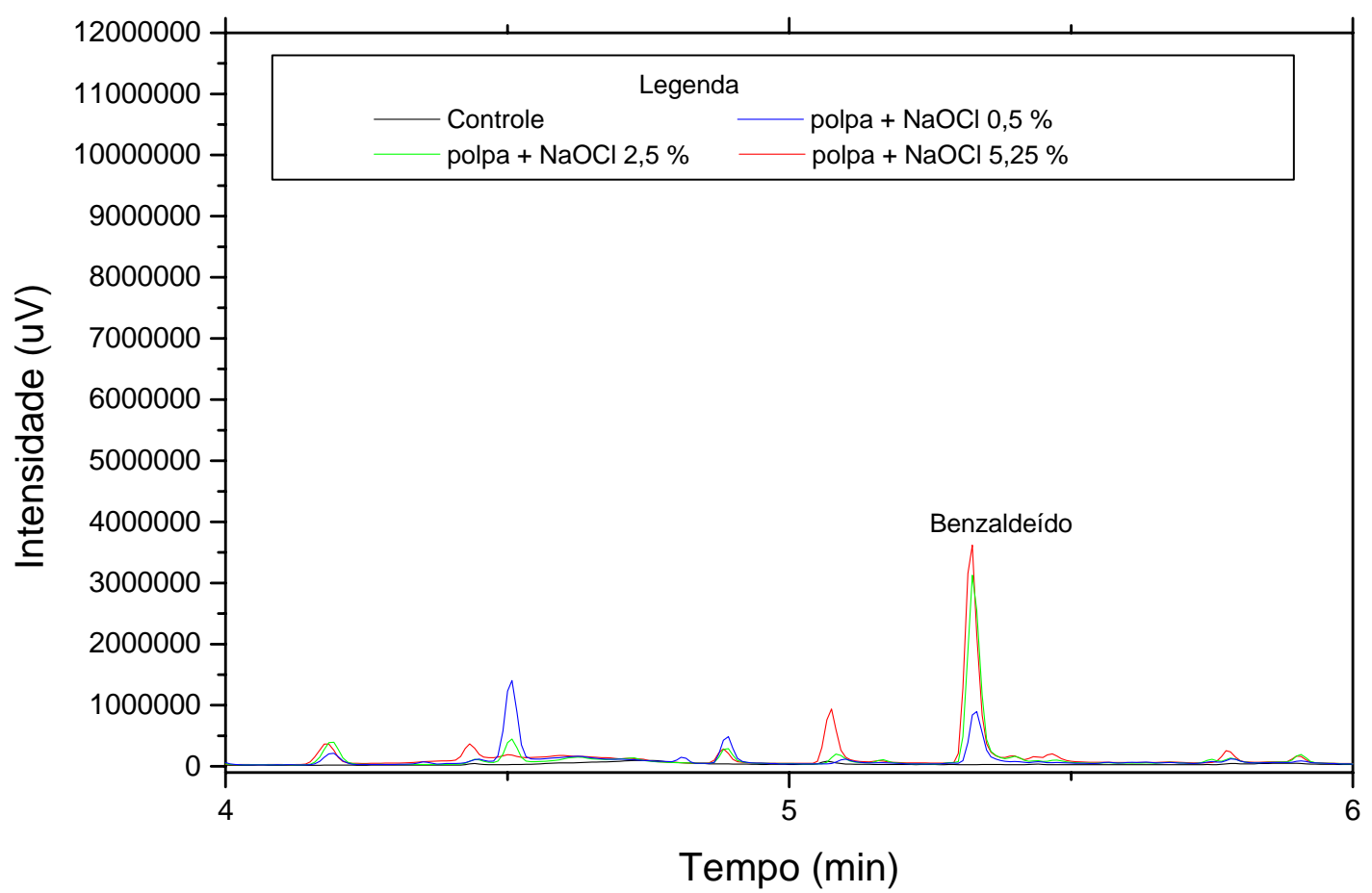

Figura 25. Zoom de 4 - 6 min da análise imediata dos produtos voláteis formados na reação entre $\mathrm{NaOCl} /$ polpa bovina. 


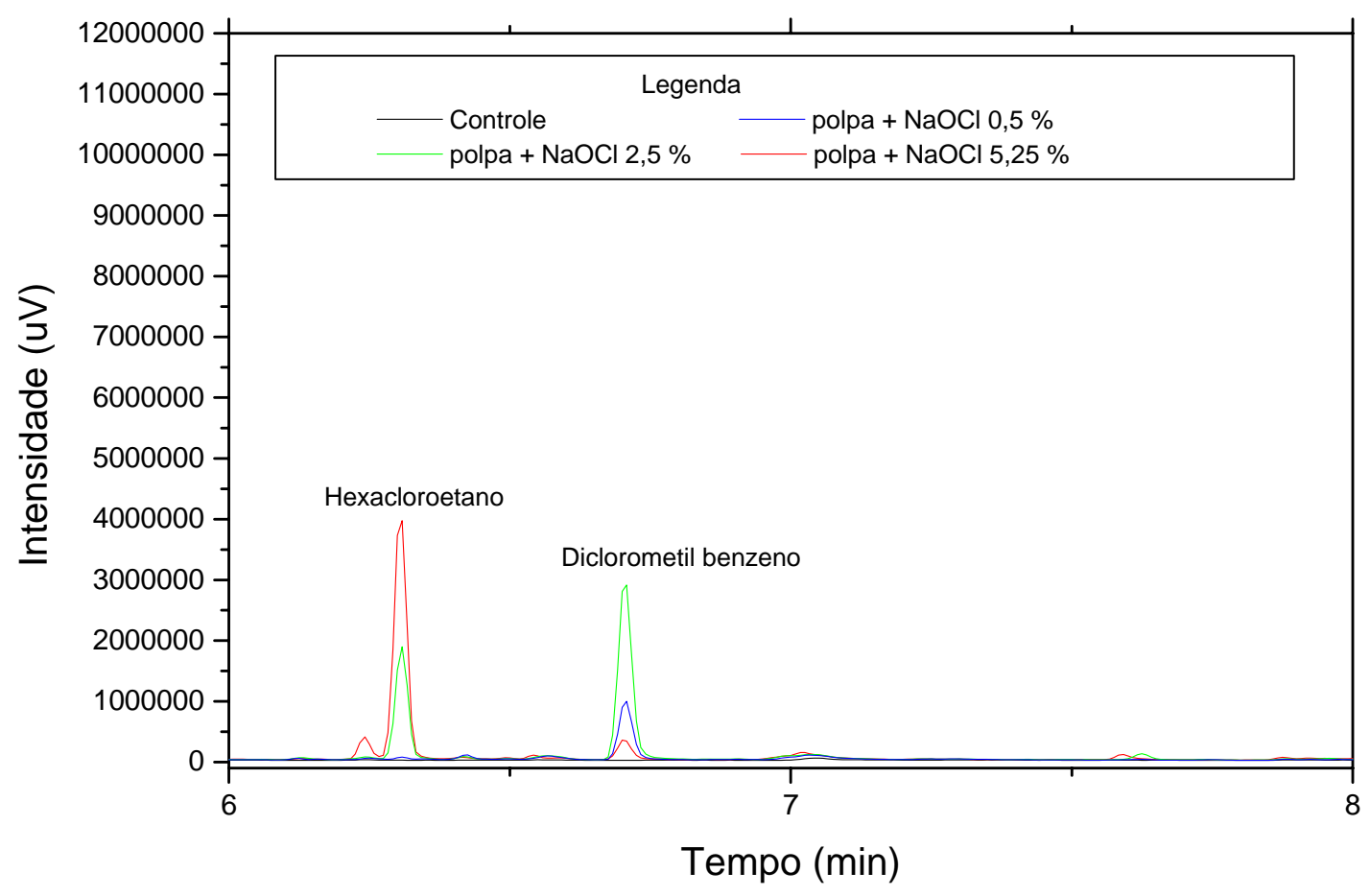

Figura 26. Zoom de 6 - 8 min da análise imediata dos produtos voláteis formados na reação entre $\mathrm{NaOCl} /$ polpa bovina.

A análise feita dos resultados obtidos pela Cromatografia Gasosa acoplada ao Espectômetro de Massas (CG-MS) mostra semelhança nos produtos originados a partir do contato do $\mathrm{NaOCl}$ em polpa ou dentina bovina: clorofórmio, benzaldeído, hexacloroetano e diclorometilbenzeno.

\section{Extração da fase aquosa}

O resultado obtido por meio do Cromatógrafo Gasoso a qual foi submetido à extração da fase aquosa do composto originado pelo contato das diferentes concentrações do $\mathrm{NaOCl}$ com a dentina e polpa bovina está ilustrado na Figura 27. 


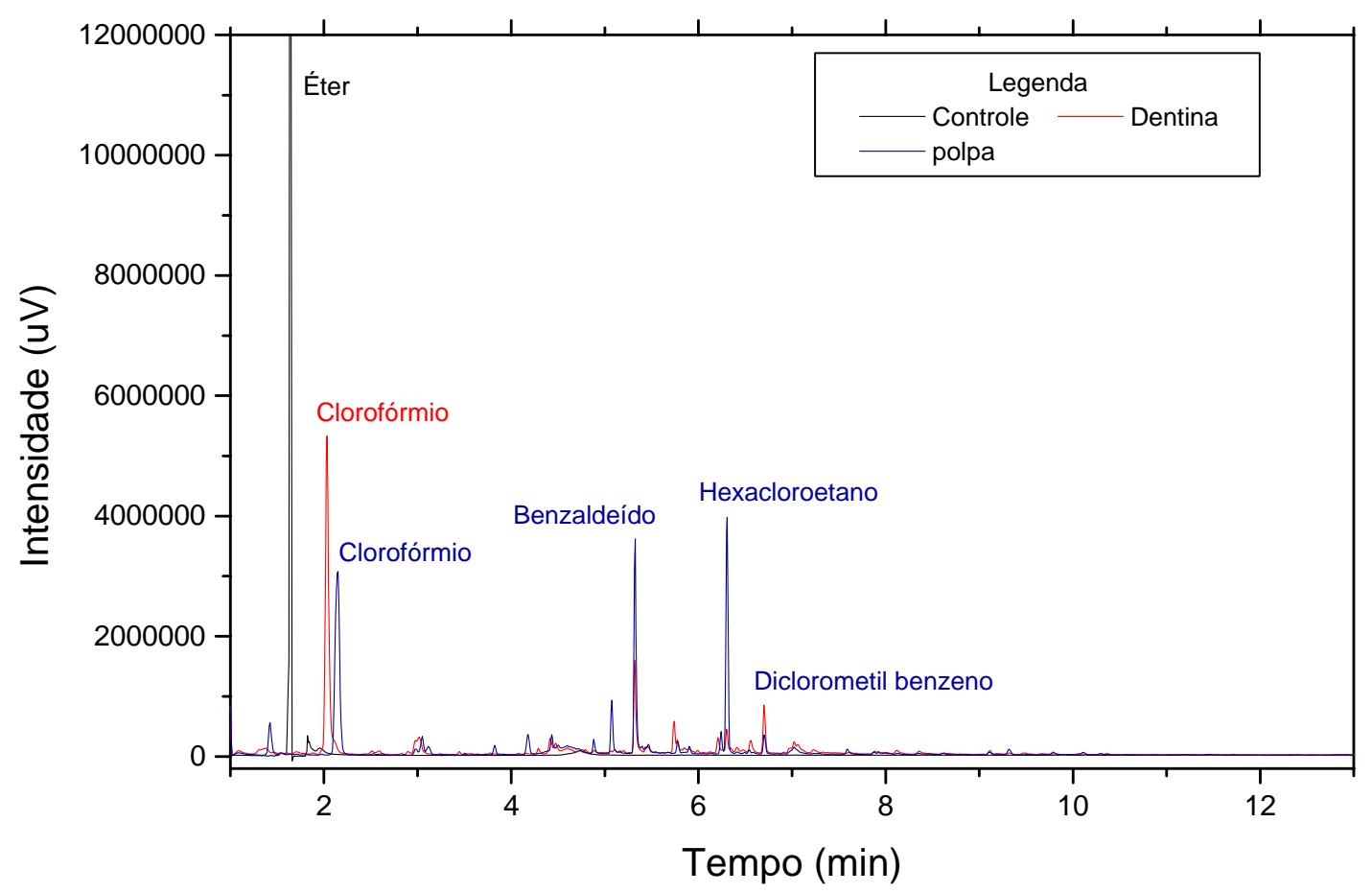

Figura 27. Extração com éter etílico da fase aquosa dos produtos formados na reação entre $\mathrm{NaOCl} 5,25 \%$ / dentina bovina e $\mathrm{NaOCl} 5,25 \%$ + / polpa bovina.

Observa-se na figura 27 a presença de um pico entre o tempo 1 - 2 min. referente ao éter etílico. A linha de cor preta é o gráfico do controle do solvente utilizado demonstrando sua identificação pelo CG-MS. Depois de identificado, o gráfico mostra-se sem qualquer outro tipo de resposta ao éter etílico pela análise de Cromatografia Gasosa acoplada ao Espectômetro de Massas.

Assim como nos resultados demonstrados pela análise dos compostos voláteis, tanto da dentina quanto da polpa bovina, na fase aquosa nota-se a formação dos mesmos compostos nos diferentes substratos: clorofórmio, benzaldeído, hexacloroetano e diclorometilbenzeno nos TRs de 2, $15 \mathrm{~min}$., 5,32 min., 6,3 min. e 6,70 min., respectivamente. 


\section{Análise das áreas dos picos obtidos na cromatografia gasosa dos compostos voláteis (relação concentração do hipoclorito de sódio e produtos gerados).}

\section{3a. Dentina Bovina}

A Tabela I informa as áreas referentes a cada pico da Figura 11 dos compostos gerados pelo contato da dentina bovina nas diferentes concentrações do $\mathrm{NaOCl}$.

\begin{tabular}{|c|c|c|c|}
\hline Pico & $\mathrm{NaOCl}(\%)$ & $\begin{array}{c}\text { Tempo de Retenção } \\
\text { (min) }\end{array}$ & Área \\
\hline & 0,5 & \multirow{3}{*}{ 2,15 (pico 1) } & 10681137 \\
\hline 1 & 2,5 & & 24501360 \\
\hline clorofórmio & 5,25 & & 24856101 \\
\hline & 0,5 & \multirow{3}{*}{ 5,32 (pico 2) } & 2045827 \\
\hline 2 & 2,5 & & 8417137 \\
\hline benzaldeído & 5,25 & & 11931805 \\
\hline \multirow{3}{*}{$\begin{array}{c}3 \\
\text { hexacloroetano }\end{array}$} & 0,5 & \multirow{3}{*}{ 6,30 (pico 3) } & 511172 \\
\hline & 2,5 & & 8887362 \\
\hline & 5,25 & & 12298806 \\
\hline \multirow{3}{*}{$\begin{array}{c}4 \\
\text { diclorometilbenzeno }\end{array}$} & 0,5 & \multirow{3}{*}{ 6,70 (pico 4) } & 1208900 \\
\hline & 2,5 & & 3045170 \\
\hline & 5,25 & & 11691997 \\
\hline
\end{tabular}

Tabela I. Áreas dos picos obtidos na cromatografia gasosa dos compostos voláteis liberados na reação entre a dentina e o hipoclorito de sódio ( $\mathrm{NaOCl})$ nas diferentes concentrações testadas.

A altura dos picos presentes na Figura 11 não corresponde à quantidade formada de cada composto. Os valores expressos na ordenada da Figura referem-se à Intensidade (uV) com que cada composto foi identificado pelo CG-MS. Assim, a quantidade formada de cada composto é expressa pela área dos picos.

No $T R=2,15$ min. da Figura 11, referente ao clorofórmio, apesar do pico de maior altura ser do $\mathrm{NaOCl}$ na concentração de $2,5 \%$, seguido pelo pico do $\mathrm{NaOCl}$ $5,25 \%$ e o mais baixo pelo $\mathrm{NaOCl} 0,5 \%$, a quantidade do composto formado segue a proporcionalidade da concentração do hipoclorito de sódio utilizado, ou seja, a concentração mais baixa do $\mathrm{NaOCl}(0,5 \%)$ resulta na menor área (10681137) de clorofórmio gerado na reação, seguida pela área de 24501360 referente à quantidade de clorofórmio resultante do contato do $\mathrm{NaOCl}$ a 2,5\% em dentina bovina 
e finalizando com a maior área, de 24856101 , do composto organoclorado resultado do uso do $\mathrm{NaOCl}$ a $5,25 \%$, expressos na tabela I. Assim, salienta-se que a geração do clorofórmio é diretamente proporcional à concentração do hipoclorito de sódio.

Referente ao benzaldeído, no $T R=5,32 \mathrm{~min}$. da Figura 11, os picos formados na variação de cada solução de $\mathrm{NaOCl}$ são proporcionais à área. 0 menor pico ( $\mathrm{NaOCl}$ 0,5\%) também é responsável pela menor área de 2045827, seguido pelo pico do $\mathrm{NaOCl} 2,5 \%$ que possui área de 8417137 , finalizando pelo maior pico, de área de 12298806 , do $\mathrm{NaOCl} 5,25 \%$.

Assim como nos picos apresentados na formação do benzaldeído, 0 hexacloroetano e o diclorometilbenzeno também possuem os picos seguindo a proporcionalidade das áreas e às concentrações do $\mathrm{NaOCl}$. O hexacloroetano (TR = 6,30 min.) apresenta o menor pico na concentração do hipoclorito de sódio à $0,5 \%$ com área de 511172. A concentração de $2,5 \%$ do $\mathrm{NaOCl}$, a segundo mais concentrada, também é o segundo maior pico e a segunda maior área, de 8887362. A solução mais concentrada, de 5,25\% apresenta maior pico na Figura 11 e possui área de 12298806.

Finalizando a análise das áreas dos picos da Figura 11, 0 diclorometilbenzeno identificado no $T R=6,7 \mathrm{~min}$. apresenta um menor pico correspondente à solução de $\mathrm{NaOCl} 0,5 \%$ e com área de 1208900 seguido pelo pico do $\mathrm{NaOCl} 2,5 \%$ dono da área de 3045170 e finalmente a maior área de 11691997 referente ao $\mathrm{NaOCl} 5,25 \%$. 


\section{3b. Polpa Bovina}

A Tabela II informa as áreas referentes a cada pico da Figura 23 dos compostos gerados pelo contato da polpa bovina nas diferentes concentrações do $\mathrm{NaOCl}$.

\begin{tabular}{|c|c|c|c|}
\hline Pico & $\begin{array}{c}\mathrm{NaOCl} \\
(\%)\end{array}$ & $\begin{array}{c}\text { Tempo de Retenção } \\
\text { (min) }\end{array}$ & Área \\
\hline & 0,5 & \multirow{3}{*}{ 2,15 (pico 1) } & 7442200 \\
\hline 1 & 2,5 & & 12190135 \\
\hline clorofórmio & 5,25 & & 12382353 \\
\hline \multirow{3}{*}{$\begin{array}{c}2 \\
\text { benzaldeído }\end{array}$} & 0,5 & \multirow{3}{*}{ 5,32 (pico 2) } & 1837003 \\
\hline & 2,5 & & 4873283 \\
\hline & 5,25 & & 6867971 \\
\hline \multirow{3}{*}{$\begin{array}{c}3 \\
\text { hexacloroetano }\end{array}$} & 0,5 & \multirow{3}{*}{ 6,30 (pico 3) } & 1393245 \\
\hline & 2,5 & & 2791955 \\
\hline & 5,25 & & 8957649 \\
\hline \multirow{3}{*}{$\begin{array}{c}4 \\
\text { diclorometilbenzeno }\end{array}$} & 0,5 & \multirow{3}{*}{6,70 (pico 4) } & 1574741 \\
\hline & 2,5 & & 4943370 \\
\hline & 5,25 & & 1115776 \\
\hline
\end{tabular}

Tabela II . Áreas dos picos obtidos na cromatografia gasosa dos compostos voláteis liberados na reação entre a polpa e o hipoclorito de sódio $(\mathrm{NaOCl})$ nas diferentes concentrações testadas.

No primeiro pico da Figura 23 no $\mathrm{TR}=2,15$ min., referente à identificação do clorofórmio, o maior pico é da resposta do CG-MS frente ao $\mathrm{NaOCl} 2,5 \%$, seguido pelo pico da formação do organoclorado quanto utilizado $\mathrm{NaOCl}$ 0,5\% e o pico mais baixo é da polpa bovina em contato com $\mathrm{NaOCl}$ a $5 \%$, porém a quantidade do clorofórmio formado não corresponde aos picos, sendo aumentada em razão proporcional ao aumento da concentração da solução halógena. A área de menor valor igual a 7442200 corresponde ao segundo maior pico ( $\mathrm{NaOCl}$ 0,5\%), seguida pela segunda maior área de valor 12190135 expressa na Tabela P cujo pico, de maior altura, está ilustrado na Figura 23 e a maior área (12382353), da Tabela II, refere-se ao menor pico.

Os picos da Figura 23 referente à formação do benzaldeído estão no TR = 5,32 min. e seguem a proporção de quanto maior o pico, maior a área da Tabela II e concentração do $\mathrm{NaOCl}$. O menor pico, referente ao $\mathrm{NaOCl} 0,5 \%$ tem área de 1837003, seguido pelo pico de área de 4872823 ( $\mathrm{NaOCl} 2,5 \%)$ e o maior pico tem área de 6867971 da formação do benzaldeído com o uso do $\mathrm{NaOCl}$ a 5,25\% . 
Os picos de identificação do hexacloroetano expressos pelo $T R=6,30 \mathrm{~min}$. pelas análises do CG-MS também são proporcionais às suas áreas e concentração do $\mathrm{NaOCl}$ utilizado. A menor área, de valor 1393254, e menor pico resultam da utilização da menor concentração do $\mathrm{NaOCl}$ proposto pelo trabalho $(\mathrm{NaOCl} 0,5 \%)$. 0 segundo maior pico é do $\mathrm{NaOCl}$ a 2,5\% e tem o valor de 2791955 para sua área. A maior área (8957649) e também maior pico são demonstrados quando se utilizou a maior concentração do $\mathrm{NaOCl}$ a 5,25\% .

No $T R=6,70$ min. da Figura 23, temos ilustrados os picos de identificação do diclorometilbenzeno que, ao contrário de todos os outros picos identificados nos resultados, o aumento concentração do $\mathrm{NaOCl}$ não originou maior quantidade do organoclorado formado. 0 maior pico, responsável pela maior área com valor de 4943370 foi originada quando se utilizou $\mathrm{NaOCl} 2,5 \%$. Quando utilizado o $\mathrm{NaOCl}$ a 0,5\%, menor concentração utilizada neste trabalho, obteve-se o segundo maior pico e a segunda maior área na formação do diclorometilbenzeno com valor de 1574741. E o uso do $\mathrm{NaOCl}$ a 5,25\% gerou a menor área e o menor pico na formação do organoclorado, com o valor de 1115776 para a área do pico ilustrado na Figura 23. 
Discussão 

A análise em cromatografia gasosa acoplada à espectrometria de massas (CGMS) mostrou-se eficaz na identificação dos produtos gerados no contato do hipoclorito de sódio com dentina ou polpa bovina.

Cromatografia é um método físico de separação no qual os componentes a serem separados se distribuem entre duas fases, uma estacionária, enquanto a outra se movimenta numa direção definida. A mistura que contem os componentes a serem separados é dissolvida na fase móvel. Durante a passagem da fase móvel através da fase estacionaria, alguns componentes são fortemente retidos e por isso se movem lentamente com o fluxo da fase móvel; enquanto isso, outros componentes interagem fracamente com a fase estacionaria, sendo transportados mais facilmente pela fase móvel. Devido a essas diferenças em mobilidade, os componentes da mistura podem ser separados e analisados de forma qualitativa e/ou quantitativa, tais como espectrofotometria ou a espectrometria de massas (IUPAC 2007).

Em um sistema de cromatografia gasosa acoplada ao espectrômetro de massas, as amostras são bombardeadas por elétrons e quebradas gerando íons positivos, negativos e radicais. A diferença na relação massa / carga dos íons gerados irá separá-los (ATKINS, 2001; EWING, 2002).

Os resultados deste trabalho mostraram que, independente das concentrações da solução de hipoclorito de sódio, há a formação dos mesmos compostos, porém o aumento da concentração é diretamente proporcional ao aumento da quantidade formada de cada um deles, sendo alguns tóxicos ao ser humano.

Os quatro compostos gerados em maior quantidade e apresentados nos resultados deste trabalho (clorofórmio, benzaldeído, hexacloroetano e diclorometilbenzeno) foram observados tanto na análise da fase volátil quanto da fase aquosa do contato do hipoclorito de sódio com dentina e polpa bovina sendo que três possuem estruturas químicas que os caracterizam como compostos organoclorados: o clorofórmio, o hexacloroetano e o diclorometilbenzeno.

O clorofórmio ou triclorometano, um organoclorado impropriamente chamado de tricloreto de formol, é altamente refrativo, não inflamável, alto peso molecular, muito volátil, odor característico e, quando em estado líquido, possui saber adocicado. Solidifica a $-63,5^{\circ}$ e atinge ponto de ebulição a $59^{\circ}$. Os resultados deste 
trabalho apontaram maior quantidade do clorofórmio nas análises dos voláteis comparado nas análises da fase aquosa. Isso é explicado pela alta volatilidade do organoclorado. SMYTH et al (1962) pesquisou o efeito do clorofórmio em ratos e afirmou a toxicidade da substância no organismo vivo apontando ainda a dose letal para a espécie por via oral no valor de $2,18 \mathrm{~g} / \mathrm{kg}$. Quando inalado em grandes doses pode causar hipotensão, depressão respiratória e cardíaca e até a morte. Esta substância é considerada uma substância carcinogênica. Ainda é utilizado como solvente de gorduras, óleos, borracha, ceras, guta-percha, como agente de limpeza, em extintores de incêndio para baixar a temperatura de congelação do tetracloreto de carbono.

O hexacloroetano, outro composto caracterizado como um organoclorado é solúvel em clorofórmio, álcool, benzeno, éter e óleos e é insolúvel em água, possui odor de cânfora. Encontrado em forma de cristal, sublima sem derreter. A dose letal em cães por meio intravenoso é de $325 \mathrm{mg} / \mathrm{kg}$ (Barsoum \& Saad, 1934). Em humanos Pode ser moderadamente irritante para pele e mucosas.

O diclorometilbenzeno é um organoclorado pouco estudado, porém os benzenos são cancerígenos. Assim mais pesquisas devem ser realizadas sobre este organoclorado.

0 benzaldeído, outra substância formada, porém que não se enquadra nos compostos organoclorados é encontrado nos grãos de amêndoas. Em seu estado líquido possui alto valor de refração, tem a cor amarelada, o odor é característico, deve ser mantido em recipiente fechado e protegido da luz. 0 ponto de ebulição é em torno de $25^{\circ}$ e o ponto de solidificação é de $-56,5^{\circ}$. A dose letal por via oral em ratos é de 1300/1000 mg/kg (JENNER et al, 1964). É utilizado na fabricação de corantes, perfumaria, como solventes e agentes aromáticos. Em altas concentrações podem causar dermatite de contato.

Acrescentam-se às reações já estudadas (PUCCI, 1945; SPANÓ et al, 2001) os conhecimentos expressos neste trabalho que pode ser visto na Figura 28 em que mostra todas as reações químicas entre os componentes do tecido pulpar e as substâncias presentes na solução de hipoclorito de sódio. 


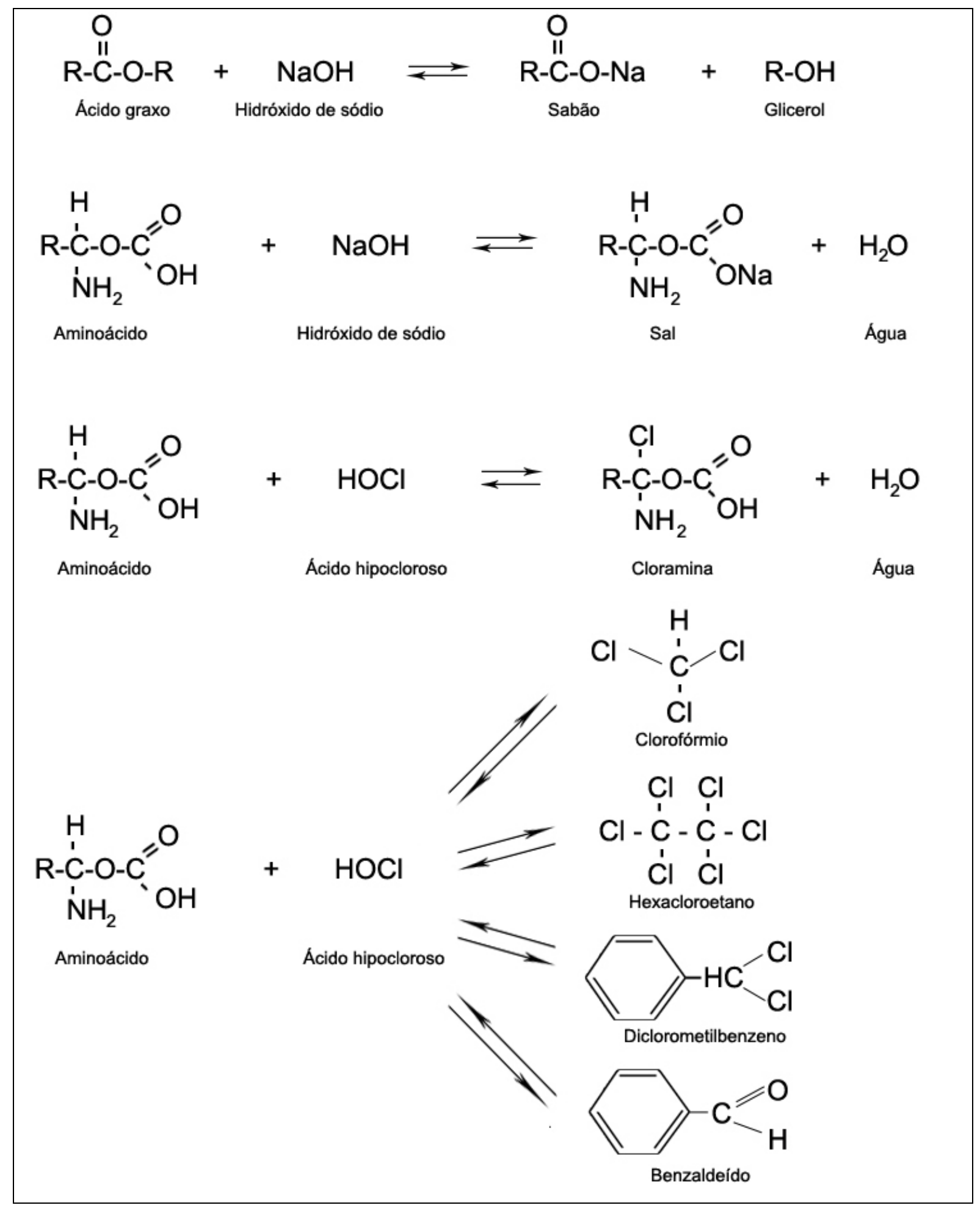

Figura 28. Reações químicas entre os componentes do tecido pulpar e as substâncias presentes na solução de hipoclorito de sódio. 
Apesar do hipoclorito de sódio ser uma das soluções irrigantes mais utilizadas há mais de um século no tratamento endodôntico pelas suas propriedades de clarificação, dissolução de tecido orgânico e necrótico (CLARKSON et al, 2006; ALJ ADAA et al, 2009; DUTTA \& SAUNDERS, 2012; CLARKSON et al, 2012), por ser eficaz em condições aeróbicas e anaeróbicas (YANG et al, 1995), saponificação (SPANÓ et al, 2001), transformação de aminas em cloraminas, desodorização e ação antimicrobiana (ESTRELA et al, 2007, ALVES et al, 2011, PAIVA et al, 2013), é necessário rever o seu uso nos atendimentos clínicos odontológicos considerando os resultados deste trabalho. A inalação pelo profissional e paciente da fase volátil dos produtos resultantes do contato do $\mathrm{NaOCl}$ com substratos orgânicos, deve ser considerada uma vez que organoclorados tendem a acumular no tecido adiposo de humanos (DE VOOGT et al, 1999) apresentando riscos à saúde (OLAYA-CONTRERAS et al, 1998; WHO, 1998; YUAN et al, 2005; SOLTANINEJ AD \& ABDOLLAHI, 2009).

Fica claro, frente aos resultados encontrados neste trabalho, que ocorre reação entre $0 \mathrm{NaOCl}$ e o substrato orgânico presente na dentina e polpa bovina com a consequente formação de substâncias, sendo algumas delas organoclorados e cancerígenas. Sabendo da toxicidade das mesmas, sugere-se que mais trabalhos sejam realizados para análise mais precisa e conclusiva sobre a quantidade dos produtos organoclorados formados durante 0 tratamento endodôntico, seus efeitos quando acumulados no organismo e a relação das ações benéficas e deletérias do uso do hipoclorito de sódio na instrumentação dos canais radiculares. 


\section{Conclusão}



Com base na metodologia empregada e nos resultados obtidos, é lícito concluir que:

1- Há formação de compostos organoclorados quando o $\mathrm{NaOCl}$ é colocado em contato com substrato orgânico (polpa ou dentina bovina);

2- A formação desses produtos ocorrem em todas as concentrações do $\mathrm{NaOCl}$ testadas $(0,5 \%, 2,5 \%$ e $5,25 \%)$;

3- Todos os produtos formados neste trabalho apresentam proporcionalidade direta com a concentração do hipoclorito de sódio utilizada, com exceção das análises dos resultados do diclorometilbenzeno na fase volátil quando o $\mathrm{NaOCl}$ foi mantido em contato com polpa bovina. 

Referências Bibliográficas 

ABDOLLAHI, M.; MOSTAFALOU, S.; POURNOURMOHAMMADI, S. et al. Oxidative stress and holinesterase inhibition in saliva and plasma of rats following subchronic exposure to malathion. Comp Biochem Physiol C Toxicol Pharmacol, v. 137, p. 29-34, 2004.

AL-JADAA, A.; PAQUÉ, F.; ATTIN, T.; ZEHNDER, M. Necrotic pulp tissue dissolution by passive ultrasonic irrigation in simulated accessory canals: impact of canal location and angulation. I nt Endod J ., v. 42, p. 59-65, 2009.

ALVES, F. R.; ALMEIDA, B. M.; NEVES, M. A. et al. Time-dependent antibacterial effects of the self-adjusting file used with two sodium hypochlorite concentrations. J Endod., v. 37, p. 1451-5, 2011.

ARI, H.; ERDEMIR, A.; BELLI, S. Evaluation of the effect of endodontic irrigation solutions on the microhardness and the roughness of root canal dentin. J Endod., v. 30, p. 792-5, 2004.

AUBUT, V.; POMMEL, L.; VERHILLE, B. et al. Biological properties of a neutralized 2.5\% sodium hypochlorite solution. Oral Surg Oral Med Oral Pathol Oral Radiol Endod., v. 109, p. 120-5, 2010.

BAIRD, C. Química Ambiental. 2 ed., capítulo 6, pags 316 - 402. Editora Bookmam, 2002a.

BAIRD, C. Química Ambiental. 2 ed., capítulo 9, pags 483 -523. Editora Bookmam, 2002b.

BARBOSA, S. V.; SAFAVI, K. E.; SPÅNGBERG, S. W. Influence of sodium hypochlorite on the permeability and structure of cervical human dentine. Int Endod J., v. 27, p. 309-12, 1994.

BARNHART, B. D.; CHUANG, A.; LUCCA, J. J. et al. An in vitro evaluation of the cytotoxicity of various endodontic irrigants on human gingival fibroblasts. J Endod., v. 31, p. 613-5, 2005.

BARRETT, M. T. The Dakin-Carrel antiseptc solution. Dent Cosmos., v. 59, p. 44648, 1917.

BARSOUM; SAAD. Quart. J. Pharm. Pharmacol., p. 7,205, 1934. 
BIGNERT, A.; OLSSON, M.; PERSSON, W. et al. Temporal trends of organochlorines in northern Europe, 1967]1995. Relation of global fractionation, leakage from sediments and international measures. Environ Pollut., v. 99, p. 177-198, 1998.

BOORMAN, G. A.; DELLARCO, V.; DUNNICK, J. K. et al. Drinking water disinfection byproducts: review and approach to toxicity evaluation. Environ. Health Perspect., v. 107 (Suppl. 1), p. 207-217, 1999.

BROUWER, A.; AHLBORG, U. G.; VAN DEN BERG, M. et al. Functional aspects of developmental toxicity of polyhalogenated aromatic hydrocarbons in experimental animals and human infants. Eur J Pharmacol., v. 293, p. 1-40, 1995.

CALLAHAN, J. R. Sulfuric acid for opening root-canals. Dent Cosmos., v. 36, n. 12, p. 957-959, 1984.

CAMPS, J.; POMMEL, L.; AUBUT, V. et al. Shelf life, dissolving action, and antibacterial activity of a neutralized $2.5 \%$ sodium hypochlorite solution. Oral Surg Oral Med Oral Pathol Oral Radiol Endod., v. 108, p. 66-73, 2009.

CANTOR, K. T. Drinking water and cancer. Cancer Causes Control, v.8, p. 292308, 1997.

CHRISTENSEN, C. E.; MCNEAL, S. F.; ELEAZER, P. Effect of lowering the $\mathrm{pH}$ of sodium hypochlorite on dissolving tissue in vitro. J Endod., v. 34, p. 449-52., 2008.

CLARKSON, R. M.; MOULE, A. J.; PODLICH, H. et al. Dissolution of porcine incisor pulps in sodium hypochlorite solutions of varying compositions and concentrations. Aust Dent J., v. 51, p. 245-51, 2006.

CLARKSON, R. M.; KIDD, B.; EVANS, G. E.; MOULE, A. J. The effect of surfactant on the dissolution of porcine pulpal tissue by sodium hypochlorite solutions. J Endod., v. 38, p. 1257-60, 2012.

COBANKARA, F. K.; OZKAN, H. B.; TERLEMEZ, A. Comparison of organic tissue dissolution capacities of sodium hypochlorite and chlorine dioxide. J Endod.,v. 36, p. 272-4, 2010.

COLBORN, T.; VOM SAAL, F. S.; SOTO, A. Developmental effects of endocrinedisrupting chemicals in wildlife and humans. Environ Health Perspect., v. 101, p. 378-384, 1993. 
DAKIN, H. D. The use of certain antiseptic substances in the treatment of infected wounds. Brit. Med. J., v. 2, p. 318-20, 1915.

DATTA, C.; GUPTA, J.; SARKAR, A. et al. Effects of organophosphorus insecticide phosphomidon $\mathrm{n}$ antioxidant defence components of human erythrocyte and plasma. Indian J Exp Biol., v. 30, p. 65-67, 1992.

DE VOOGT, P.; WELLS, D. E.; REUTERGARDH, L.; BRINKMAN, UATH. Biological activity, determination and occurrence of planar, mono- and di-ortho PCBs. Intern. J. Environ. Anal. Cham.,v. 40,p. 1-46, 1999.

DEUS, Q. D. de Endodontia, 5 ed., Rio de Janeiro, Medsi, 1992.

DEWAILLY, E.; DODIN, S.; VERREAULT, R. et al. High organochlorine body burden in women with estrogen receptor-positive breast cancer. J Natl Cancer I nst., v. 86, p. 232-234,1994.

DUTTA, A.; SAUNDERS, W. P. Comparative evaluation of calcium hypochlorite and sodium hypochlorite on soft-tissue dissolution. J Endod., v. 38, p. 1395-8, 2012.

ESTRELA, C.; ESTRELA, C. R.; DDECURCIO, D. A. et al. Antimicrobial efficacy of ozonated water, gaseous ozone, sodium hypochlorite and chlorhexidine in infected human root canals. Int Endod J , v. 40(2), p. 85-93, 2007.

ESTRELA, C.; RIBEIRO, R. G.; ESTRELA, C. R. Antimicrobial effect of $2 \%$ sodium hypochlorite and $2 \%$ chlorhexidine tested by different methods. Braz Dent J ., v. 14, p. 58-62, 2003.

EXON, J. H.; KERKVLIET, N. I.; TALCOTT, P. A. Immunotoxicity of carcinogenic pesticides and related chemicals. Environ Carcin Rev. J Environ Sci Health C5, p. $73-120,1987$.

FALCK, F.; RICCl, A.; WOLFF, M. S. et al. Pesticides and polychlorinated biphenyl residues in human breast lipids and their relation to breast cancer. Arch Environ Health., v. 47, p. 143-146, 1992.

GERNHARDT, C. R.; EPPENDORF, K.; KOZLOWSKI, A. et al. Toxicity of concentrated sodium hypochlorite used as an endodontic irrigant. Int Endod J., v. 37, p. 272-80, 2004. 
GLYNN, A. W.; WERNROTH, L.; ATUMA, S. et al. PCB and chlorinated pesticide concentrations in swine and bovine adipose tissue in Sweden 1991]1997: spatial and temporal trends. Sci Total Environ., v. 246, p. 195-206, 2000.

GOLDBERG, M.; TAKAGI, M. Dentine proteoglycans: composition, ultrastructure and functions. Histochem. J., v. 25, p. 781-806, 1993.

GOMES, B. P.; MARTINHO, F. C.; VIANNA, M. E. Comparison of $2.5 \%$ sodium hypochlorite and $2 \%$ chlorhexidine gel on oral bacterial lipopolysaccharide reduction from primarily infected root canals. J Endod., v. 35, p. 1350-3, 2009.

GROSSMAN, L. I. Endodontic treatment of pulpless teeth. J Am Dent Assoc., v. 61, n. 6, p. 671-676,1960.

GROSSMAN, L. I.; MEIMAN, B. W. Solution of pulp tissue by chemical agents. J Am Dent Assoc., v. 28, p. 223-225, 1941.

GROSSMAN, L. I. Irrigation of root canals. J Am Dent Assoc., v. 30, p. 1915-7, 1943.

GRÜNDLING, G .L.; ZECHIN, J. G.; JARDIM, W. M. Effect of ultrasonics on Enterococcus faecalis biofilm in a bovine tooth model. J Endod., v. 37, p. 112833, 2011.

GUERISOLI, D. M. Z.; SOUSA-NETO, M. D.; PÉCORA, J. D. Ação do hipoclorito de sódio em diversas concentrações sobre a estrutura dentinária. Revista de Odontologia da Universidade de Ribeirão Preto, v. 1, p. 7-11, 1998.

GÜTTES, S.; FAILING, K.; NEUMANN, K. et al. Chlororganic pesticides and polychlorinated biphenyls in breast tissue of women with benign and malignant breast disease. Arch Environ Contam Toxicol., v. 35, p. 140-147, 1998.

HADDAD, S.; POULIN, P.; KRISHNAN, K. Relative lipid content as the sole mechanistic determinant of the adipose tissue: blood partition coefficients of highly lipophilic organic chemicals. Chemosphere, v. 40, p. 839-43, 2000.

HASHEM A. A.; GHONEIM, A. G.; LUTFY, R. A.; FODA, M. Y.; OMAR, G. A. Geometric analysis of root cannals prepared by four Rotary NiTi shaping systems. J Endod., $v$. 38, p. 996-1000, 2012. 
HERREN-FREUND, S. L.; PEREIRA, M. A. Carcinogenicity of by products of disinfection in mouse and rat liver. Environ. Health Perspect., v. 69, p. 59-65, 1986.

HOLLAND, R.; SOARES, I. J.; SOARES, I. M. Influence of irrigation and intracanal dressing on the healing process of dog's teeth with apical periodontitis. Endod Dent Traumatol., v. 8, p. 223-29, 1992.

HOYER, A. P.; GRANDJEAN, P.; JORGENSEN, T. et al. Organochlorine exposure and risk of breast cancer. Lancet, v. 352, p. 1816-20, 1998.

HUISMAN, M.; KOOPMAN-ESSEBOM, C.; FIDLER, V. et al. Perinatal exposure to polychlorinated biphenyls and dioxins and its effect on neonatal neurological development. Early Hum Dev., v. 41, p. 111-27, 1995.

I NGLE, J . I.; ZELDOW, B. J. An evaluation of mechanical instrumention and negative culture in endodontic therapy. J Am Dent Assoc., v. 57, n. 4, p. 471-76, 1958.

IRALA, L. E.; GRAZZIOTIN-SOARES, R.; SALLES, A. A. et al. Dissolution of bovine pulp tissue in solutions consisting of varying $\mathrm{NaOCl}$ concentrations and combined with EDTA. Braz Oral Res., v. 24, p. 271-6, 2010.

ISCAN, M.; COBAN, T.; COK, I. et al. The organochlorine pesticide residues and antioxidant enzyme activities in human breast tumors: is there any association? Breast Cancer Research and Treatment, v. 72, p. 173-82, 2002.

IUPAC. International Union of Pure and Applied Chemistry. Gold Book. 2007. Disponível em http://goldbook.iupac.org/A00496.html. Acessado em out. 2011.

IVANCEV-TUMBAS, I.; DALMACIJAM, B.; TAMAS, Z.; et al. The effect of different drinking water treatment processes on the rate of chloroform formation in the reactions of natural organic matter with hypochlorite. Wat. Res., v. 33, p. 3715-22, 1999.

JENNER, P. M. et al. Food Cosmet. Toxicol., v. 2, p. 327, 1964.

JUNGBLUTH， H.; MARENDING, M.; DE-DEUS, G. et al. Stabilizing sodium hypochlorite at high pH: effects on soft tissue and dentin. J Endod., v. 37, p. 693-6, 2011. 
KAMBURIS, J. J.; BARKER, T. H.; BARFIELD, R. D. et al. Removal of organic debris from bovine dentin shavings. J Endod., v. 29, p. 559-561, 2003.

KARAMI-MOHAJERI, S.; ABDOLLAHI, M. Toxic influence of organophosphate, carbamate, and organochlorine pesticides on cellular metabolism of lipids, proteins, and carbohydrates: a systematic review. Hum Exp Toxicol., v. 30(9), p. 1119-40, 2011.

KIRK, E. C. Sodium peroxid. A new dental bleaching agente and antiseptic. Dent Cosmos., v. 35, n. 2, p. 192-8, 1893.

KOIVUSALO, M.; PUKKALA, E.; VARTIAINEN, T. Drinking water chlorination and cancer - a historical cohort study in Finland. Cancer Causes Control, v. 8, p. 192200, 1997.

KOOPMAN-ESSEBOM, C.; WIESGLAS-KUPERUS, N.; DE RIDDER, M. A. J. et al. Effects of polychlorinated biphenylrdioxin exposure and feeding type on infants' mental and psychomotor development. Pediatr Res., v. 97, p. 700-6, 1996.

LEONARDO, M. R.; LEAL, J. M. Endodontia: tratamento de canais radiculares. $2^{\circ}$ ed., São Paulo, Panamericana, 1991.

LINDE, A.; ROBINS, S. P. Quantitative assessment of collagen crosslinks in dissected predentin and dentin. Coll. Relat. Res., v. 8, p. 443-50, 1988.

LU, W. Q.; CHEN, D.; WU, X .J. et al. DNA damage caused by extracts of chlorinated drinking water in human derived liver cells (HepG2). Toxicology., v. 198 (1-3),p. 351-57, 2004.

LU, W. Q.; CHEN, X. N.; YUE, F. et al. Studies on the in vivo and in vitro mutagenicity and the lipid peroxidation of chlorinated surface (drinking) water in rats and metabolically competent human cells. Mutat. Res., v. 513 (1-2), p. 151-57, 2002.

MANNAN, G.; SMALLWOOD, E. R.; GULABIVALA, K. Effect of access cavity location and design on degree and distribution of instrumented root canal surface in maxillary anterior teeth. I nt Endod J., v. 34, p. 176-183, 2001.

MEHRA, P.; CLANCY, C.; WU, J. Formation of a facial hematoma during endodontic therapy. J Am Dent Assoc., v. 131, p. 67-71, 2000. 
METZGER, Z.; TEPEROVICH, E.; ZARY, R.; COHEN, R.; HOF, R. The self-adjusting file (SAF): part 1-respecting the root canal anatomy: a new concept of endodontic files and its implementation J Endod., v. 36, p. 679-90, 2010.

MILANO, N. F.; KOLLING, I. G.; FACHINNI, B. F. Tensão superficial de alguns auxiliares químicos usados em Endodontia. RGO, v. 31, p. 37-38, 1963.

MOREIRA, D. M.; ALMEIDA, J. F.; FERRAZ, C. C. et al. Structural analysis of bovine root dentin after use of different endodontics auxiliary chemical substances. J Endod., v. 35, p. 1023-27, 2009.

MOSER, G. J .; MEYER, S. A.; SMART, R. C. The chlorinated pesticide Mirex is a novel nonphorbol ester-type tumor promoter in mice skin. Cancer Res., v. 52, p. 631-36, 1992.

MUSSALO-RAUHAMAA, $H$. Partitioning and levels of neutral organochlorine compounds in human serum, blood cells and adipose and liver tissue. Sci Total Environ., v. 103, p. 159-75, 1991.

MUSSALO-RAUHAMAA, H.; HASANEN, E.; PYYSALO, $\mathrm{H}$. et al. Occurrence of betahexachlorocyclohexane in breast cancer patients. Cancer, v. 66, p. 2124-28, 1990.

OLAYA-CONTRERAS, P.; RODRIGUEZ, V. J.; VALENCIA, H. J. et al. Organochlorine exposure and breast cancer risk in Colombian women. Cad Saude Publica, v. 14 (suppl 3), p. 125-32, 1998.

PAIVA, S. S.; SIQUEIRA, J. F. JR.; RÔÇAS, I. N. et al. Molecular microbiological evaluation of passive ultrasonic activation as a supplementary disinfecting step: a clinical study. J Endod., v. 39, p. 190-4, 2013.

PAIVA, S.S.; SIQUEIRA, J.F. JR.; RÔÇAS I.N.; et al.Clinical antimicrobial efficacy of $\mathrm{NiTi}$ rotary instrumentation with $\mathrm{NaOCl}$ irrigation, final rinse with chlorhexidine and interappointment medication: a molecular study. I nt Endod J., v. 2012 Jul 10. doi: 10.1111/j.1365-2591.2012.02111.x. [Epub ahead of print]

PALAZZI, F.; MORRA, M.; MOHAMMADI, Z. et al. Comparison of the surface tension of $5.25 \%$ sodium hypochlorite solution with three new sodium hypochloritebased endodontic irrigants. Int Endod J., v. 45, p. 129-35,2012 
PAQUÉ, F.; PETERS, O. A. Micro-computed tomography evaluation of the preparation of long oval root canals in mandibular molars with the self-adjusting file. J Endod., v. 37, n.4, p. 517-21, 2011.

PATANDIN, S.; LANTING, C. I.; MULDER, P. G. H. et al. Effects of environmental exposure to polychlorinated biphenyls and dioxins on cognitive abilities in Dutch children at 42 months of age. J Pediatr., v. 134, p. 33-41, 1999.

PÉCORA, J. D.; SOUSA-NETO, M. D.; GUERISOLI, D. M. Z. et al. Effect of reduction of the surface tension of different concentrations of sodium hypochlorite solutions on radicular dentine permeability. Braz. Endod. J., v. 3, p. 38-40, 1998.

PÉCORA, J. D.; GUIMARÃES, L. F.; SAVIOLI, R. N. Surface tension of several Drugs Used in Endodontics. Braz Dent J., v. 2, p. 123-27, 1992.

PETERS, O. A.; LAIB, A.; GOHRING, T. N.; et al. Changes in root canal geometry after preparation assessed by high-resolution computed tomography. J Endod., v. 27, p. 1-6, 2001.

PICHON, V. Solid-phase extraction for multiresidue analysis of organic contaminants in water J. Chromatogr., v. 885, p. $195-215,2000$.

PUCCl, F. M. Conductos Radiculares. Montevideo, Barreiro Y Ramos, v. 1, p. 91104, 1945.

RAHIMI, R.; ABDOLLAHI, M. A review on the mechanisms involved in hyperglycemia induced by rganophosphorus pesticides. Pestic Biochem Physiol., v. 88, p. 11521, 2007.

RETAMOZO, B.; SHABAHANG, S.; JOHNSON, N. et al. Minimum Contact Time and Concentration of Sodium Hypochlorite Required to Eliminate Enterococcus faecalis. J Endod., v. 36, p. 520-23, 2010.

RIBEIRO, E. M.; SILVA-SOUSA, Y. T.; SOUZA-GABRIEL, A. E. et al. Debris and smear removal in flattened root canals after use of different irrigant agitation protocols.

Microsc Res Tech., v. 75, p. 781-90, 2012.

RICHARDSON, S. D.; PLEWA, M. J.; WAGNER, E. D. et al. Occurrence, genotoxicity, and carcinogenicity of regulated and emerging disinfection byproducts in drinking water: a review and roadmap for research. Mutat. Res., v. 636 (1-3), p. 178-242, 2007. 
RÔÇAS, I. N.; SIQUEIRA, J. F. JR.; Comparison of the in vivo antimicrobial effectiveness of sodium hypochlorite and chlorhexidine used as root canal irrigants: a molecular microbiology study. J Endod., v. 37, p. 143-50, 2011b.

RÔÇAS, I. N.; SIQUEIRA, J. F. JR. In vivo antimicrobial effects of endodontic treatment procedures as assessed by molecular microbiologic techniques. J Endod., v. 37, p. 304-10, 2011 a.

ROSSI-FEDELE, G.; DE FIGUEIREDO, J. A. Use of a bottle warmer to increase $4 \%$ sodium hypochlorite tissue dissolution ability on bovine pulp. Aust Endod J., v. 34, p. 39-42, 2008.

ROTHMAN, N.; CANTOR, K. P.; BLAIR, A. et al. A nested case-control study of nonHodgkin lymphoma and serum organochlorine residues. Lancet, v. 350, p. 240-44, 1997.

SANDERS, G.; EISENREICH, S. J.; JONES, K. C. The rise and fall of PCBs: time trend data from temperate industrial countries. Chemosphere, v. 29, p. 9-11, 1994.

SAQUY, P. C.; SOUSA-NETO, M. D.; PÉCORA, J. D. et al. Avaliação da Capacidade Quelante do Edta e da Associação Edta Mais Solução de Dakin, Por Métodos Químicos e Pela Análise da Microdureza da Dentina. Revista Brasileira de Odontologia, v. 52, p. 51-55, 1995.

SCHILDER, H. Cleaning and shaping the root canal. Dent Clin North Am., v. 18, n. 2, p. 269-96, 1974.

SEET, A. N.; ZILM, P. S.; GULLY, N. J.; et al. Qualitative comparison of sonic or laser energisation of $4 \%$ sodium hypochlorite on an Enterococcus faecalis biofilm grown in vitro. Aust Endod J., v. 38, p. 100-6, 2012.

SHARPE, R. M.; SKAKKEBAEK, N. E. Are oestrogens involved in falling sperm counts and disorders of the male reproductive tract. Lancet, v. 341, p. 1392-95, 1993.

SIM, T. P.; KNOWLES, J. C.; NG, Y. L. et al. Effect of sodium hypochlorite on mechanical properties of dentine and tooth surface strain. Int Endod J., v. 34, p. $120-32,2001$.

SIQUEIRA JR, J. F. Treatment of Endodontic Infections. London: Quintessence Publishing; 2011. 
SIRTES, G.; WALTIMO, T.; SCHAETZLE, M.; ZEHNDER, M. The effects of temperature on sodium hypochlorite short-term stability, pulp dissolution capacity, and antimicrobial efficacy. J Endod., v. 31, p. 669 -71, 2005.

SMYTH, H. F. et al. Am. Ind. Hyg. Assoc. J., v. 23, p. 95, 1962.

SOLTANINEJAD, K.; ABDOLLAHI, M. Current opinion on the science of organophosphate pesticides and toxic stress: a systematic review. Med Sci Monit., v. 15, p. RA75-RA90, 2009.

SOUZA, R. A.; SOUSA, Y. T.; DE FIGUEIREDO, J. A. Influence of apical foramen lateral opening and file size on cemental canal instrumentation. Braz Dent J .,v. 23, p. $122-6,2012$.

SPANÓ, J. C.; BARBIN, E. L.; SANTOS, T. C. et al. Solvent action of sodium hypochlorite on bovine pulp and physico-chemical properties of resulting liquid. Braz Dent J., v. 12, p. 154-7, 2001.

STEWART, G. G. The importance of chemomechanical preparation of the root canal. Oral Surg Oral Med Oral Pathol., v. 8, n. 9, p. 993-97, 1955.

STOJICIC, S.; ZIVKOVIC, S.; QIAN, W. et al. Tissue dissolution by sodium hypochlorite: effect of concentration, temperature, agitation, and surfactant. J Endod., v. 36, p. 1558-62, 2010.

TAO, X.; ZHU, H.; MATANOSKI, G. M. Mutagenic drinking water and risk of male esophageal cancer: a population-based case-control study. Am. J. Epidemiol., v. 150, p. 443-51, 1999.

TAYLOR, H. D.; AUSTIN, J. H. The solvent action of antisseptics on necrotic tissue. The J ournal of Experimental Medicine, v. 27, p. 558-61, 1918.

TEN CATE, A. R. Oral histology: Development, Structure, and Function. (fourth ed.), Mosby, St. Louis (1994).

TOPPARI, J.; LARSEN, J. C.; CHRISTIANSEN, P.; et al. Male reproductive health and environmental xenoestrogens. Environ Health Perspect., v. 104_Suppl4., p. 741803, 1996. 
VERSIANI, M. A.; PÉCORA, J. D.; DE SOUSA-NETO, M. D. Flat-oval root canal preparation with self-adjusting file instrument: a micro-computed tomography study. J Endod., v. 37, n. 7, p. 1002-07, 2011.

WALKER, A. A definite and dependable therapy for pulpless teeth. J Am Dent Assoc., v. 23, p. 1418-25, 1936.

WANG, R.; WEINER, S. Human root dentin: structural anisotropy and Vickers microhardness isotropy. Connect. Tissue Res., v. 39, p. 269-79, 1998.

WANG, Z.; SHEN, Y.; HAAPASALO, M. Effectiveness of Endodontic Disinfecting Solutions against Young and Old Enterococcus faecalis Biofilms in Dentin Canals. J Endod., v. 38, p. 1376-79, 2012.

WASSERMANN, M.; NOGUERIA, D. P.; TOMATIS, L. et al. Organochlorine compounds in neoplastic and adjacent apparently normal breast tissue. Bull Environ Contam Toxicol., v. 15, p. 478-83, 1976.

WEINE, F. S. Endodontic therapy. $2^{\circ}$ ed., St Louis, CV Mosby, 1976.

WEISGLAS-KUPERUS, N.; SAS, T. C. J.; KOOPMAN-ESSEBOM, C. et al. Immunologic effects of background prenatal and postnatal exposure to dioxins and polychlorinated biphenyls in Dutch infants. Pediatr Res., v. 38, p. 404-10, 1995.

WHO. Consultation on assessment of the health risk of dioxins; re-evaluation of the tolerable daily intake (TDI). Food Addit. Contam., v. 17 (4), p. 223-40, 1998.

WHO. Guidelines for Drinking Water Quality, $2^{\text {nd }}$ ed. In Health criteria and other supporting information, vol. 2. WHO, Geneva, 1996.

WOLFF, M. S.; TONIOLO, P. G.; LEE, E. W. et al. Blood levels of organochlorine residues and risk of breast cancer. J Natl Cancer I nst., v. 85, p. 648-52, 1993.

YANG, S. F.; RIVERA, E. M.; BAUMGARDNER, K. R. et al. Anaerobic tissuedissolving abilities of calcium hydroxide and sodium hypochlorite. J Endod., v. 21, p. 613-16, 1995.

YUAN, J.; LIU, H.; ZHOU, L. H. et al. Oxidative stress and DNA damage induced by a drinking-water chlorination disinfection byproduct 3-chloro-4- (dichloromethyl)-5hydroxy-2(5H )-furanone (MX) in mice. Mutat. Res., v. 609 (2), p. 129-36, 2006. 
YUAN, J.; WU, X. J.; LU, W. Q. et al. Chlorinated river and lake water extract caused oxidative damage, DNA migration and cytotoxicity in human cells. Int. J. Hyg. Environ. Health., v. 208, p. 481-88, 2005.

ZEHNDER, M. Root canal irrigants. J Endod., v. 32, p. 389-98, 2006.

ZEHNDER, M.; KOSICKI, D.; LUDER, H.; et al. Tissue-dissolving capacity and antibacterial effect of buffered and unbuffered hypochlorite solutions. Oral Surg Oral Med Oral Pathol Oral Radiol Endod., v. 94, p. 756-62, 2002. 